\title{
RECENT DEVELOPMENT AND CHALLENGES IN SYNTHESIS OF CELLULOSIC NANOSTRUCTURES AND THEIR APPLICATION IN DEVELOPING PAPER-BASED ENERGY DEVICES
}

\author{
FIROOZEH DANAFAR \\ Department of Chemical Engineering, Faculty of Engineering, \\ Shahid Bahonar University of Kerman, Kerman, Iran \\ Corresponding author: danafar@uk.ac.ir
}

Received August 25, 2019

\begin{abstract}
Cellulose can be extracted from different natural sources, including plants, marine animals, or microorganisms. Nanocellulose (NC) can be then produced from it, in the form of either crystal or fiber, depending on the source of cellulose and process conditions. In the last decades, the interest in the application of NC as a building block in functional composites has significantly increased. Such a trend will keep growing due to the exceptional properties and sustainability of NC. Paper energy devices have been developed for various applications, especially those related to harvesting and saving energy. This article first briefly reviews the fundamentals related to the NC and its synthesis, and then describes thoroughly the functionalities provided by paper-based energy devices. Although these functionalities bring a great opportunity to develop new value-added products, there are several challenges in the way of commercialization of paper-based electronic and electrical devices. These challenges are summarized to open up avenues of further research, in addition to providing novel ideas for developing such devices.
\end{abstract}

Keywords: nanocellulose, cellulose, paper-based energy devices

\section{INTRODUCTION}

Developing low-cost and renewable resources is important to meet up the energy demands and resolve the environmental problems associated with the disposal of electronic and electrical devices. Currently, the major portion of the global energy demand is supplied by fossil fuels, which are limited resources. Besides, fossil fuels have low efficiency of power generation and cause air pollution. Finding a sustainable manner to supply energy by using clean fuel derived from renewable resources of energy has become a global initiative. The major problem concerned with renewable resources of energy, like solar and wind, is that they are periodic, thus the energy comes in pulses rather than in a steady stream. Developing eco-friendly power sources and storing energy in batteries, capacitors and fuel cells can help solve this problem. Replacing the metals used in these devices with naturally decomposable conductive composites will help reduce tons of $\mathrm{CO}_{2}$ emission. The increase of electronic wastes, which are not naturally decomposable, is also one of the major environmental concerns noted these days. New insights into developing conductive biopolymers, which are environmentally friendly, encourage researchers to focus on using natural polymers, such as cellulose, chitosan, starch etc. Cellulose, as the most abundant sustainable resource, is extensively under survey for developing a new generation of electronic and electrical devices.

Cellulose, a fascinating biopolymer, is widely distributed in the nature in plants, microorganisms and some animals. Independently of its source, cellulose is a linear polymer of Danhydroglucopyranose units linked together by $\beta$ 1,4-glucosidic bonds. Any physical or chemical modification of the cellulose chain will change its molecular structure and thus such a versatile structuring of cellulose has enabled its diverse applications (e.g., as a filler in novel functional materials, coatings and laminates, paper electronics, smart textiles, optical films, sorption media and viscosity regulators). The application 
fields of cellulose tend to extend, as it is anticipated that the world market of cellulose nanostructures will reach about 37 billion dollars in $2020{ }^{1}$

The application of cellulosic structures in the energy sector has been extensively studied for biofuel production. ${ }^{2-4}$ Moreover, cellulosic materials can be effectively used in developing biocompatible products as a replacement of petroleum-based plastics. These materials also are excellent for fabrication of energy-efficient devices, such as paper batteries, super-capacitors, insulators, paper displays, electric heaters and antistatic coatings. ${ }^{5}$ Cellulosic nanostructures have several advantages in developing biocompatible composites and paper-based energy devices due to their supreme physical and chemical properties. The superiority of cellulosic nanostructures, compared to other widely used nanostructures, such as fullerenes and carbon nanotubes, lies in their biodegradability, renewability, sustainability, abundance and high biocompatibility.

Nanocellulose can be produced in the form of either crystal or fiber, depending on the source of cellulose and process conditions. Nanostructures have unique reinforcing properties, including high elastic modulus, high specific strength, high elasticity, dimensional stability, and low thermal expansion coefficient. ${ }^{6}$ These properties, along with the low density and high aspect ratio, make $\mathrm{NC}$ attractive to be used as reinforcing element in composites. The high surface area of NC also makes it a strong adsorbent. Moving to the nanometer scale, some exceptional properties appear. For example, cellulose is known as an insulating material, while NC is conductive and transparent. The reason for these unique optical properties of nanocellulose lies in its nano-size, being on the same scale as the critical size for light transmission.

Despite its diverse applications, the efficient separation of cellulosic nanostructures is a major challenge, limiting the wide utilization of these renewable components. The morphology and hence the properties of regenerated cellulose depend on the source of cellulose, the technique and the operation conditions used. ${ }^{7}$ For instance, depending on the substrate and pretreatment steps, the regenerated cellulose can be transparent or opaque. The source of cellulose also determines some important properties and characteristics, such as shape and size distribution of crystalline nanoparticles and their aspect ratio..$^{8-9}$ The current paper aims to review the recent advancements in the extraction of cellulosic nanostructures, as well as to present recent progress in the development of energy and electronics devices using NC. Before going into the applications of NC, it is necessary to provide a brief explanation on the cellulose structure and its extraction techniques.

\section{CELLULOSE SOURCES}

Cellulose is the most abundant natural polymer derived from biomass, including plants, some sea animals, and microorganisms (Fig. 1). Despite the similar structure, the cellulose derived from each source has several different characteristics. The following paragraph presents the characteristics of cellulose extracted from different sources.

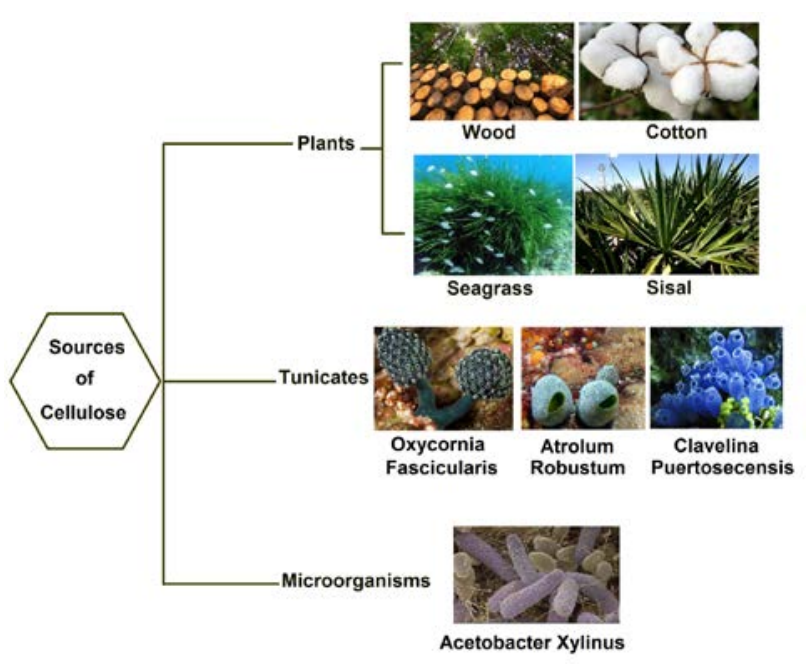

Figure 1: Different sources of cellulose 


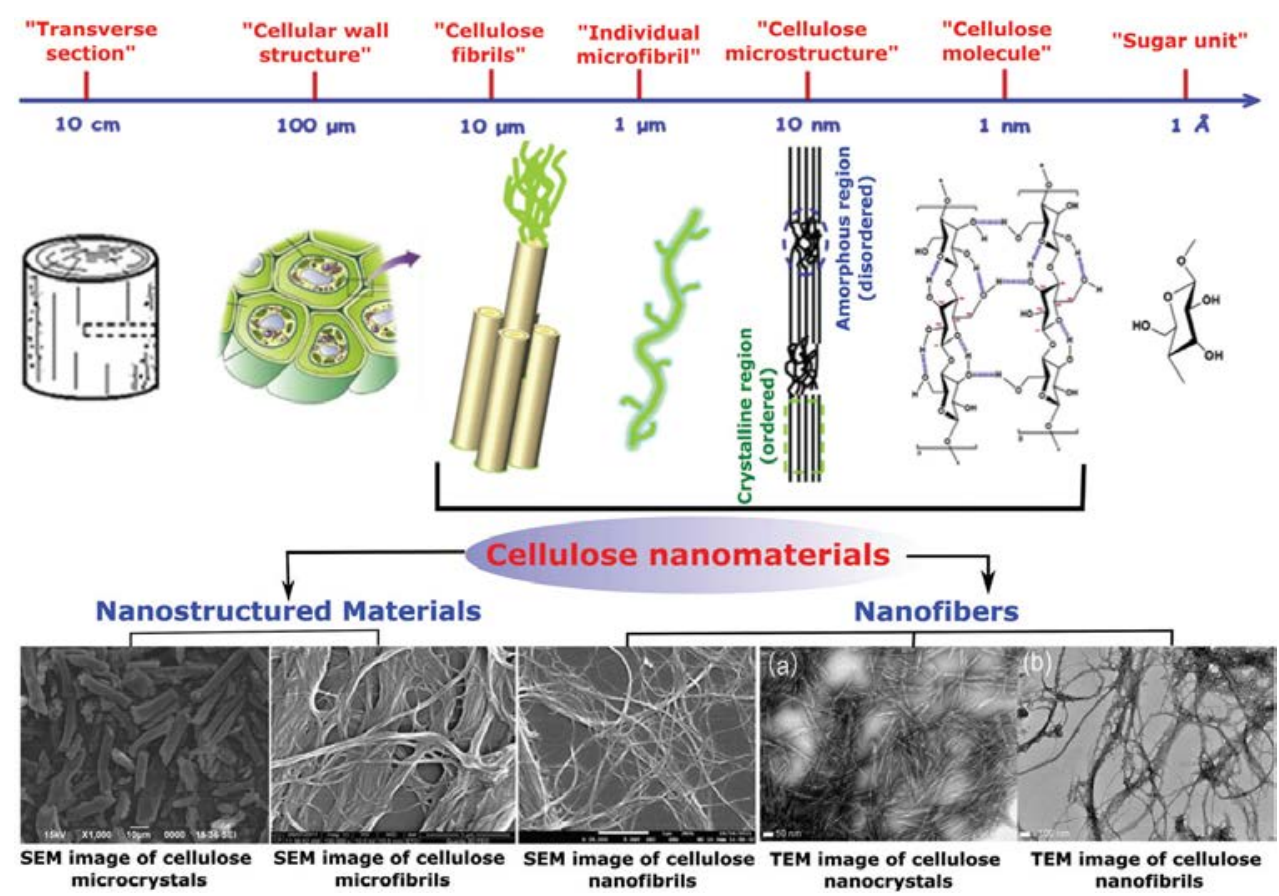

Figure 2: Hierarchical structure of cellulose and its nano-sized types (with permission ${ }^{12}$ )

\section{Cellulose from plants}

Plants or agricultural wastes, including woody or non-woody plants, such as cotton, hemp, jute and sisal, as well as sea grass species, such as Posidonia oceanic, are the major source of cellulose. The tubular structure of the cell wall in plants comprises a helically wound arrangement of cellulose nanofibers with a width of 1.5-3.5 nm and length of $1 \mu \mathrm{m}$ and above. ${ }^{10}$ These nanofibers, mostly known as cellulose microfibrils, consist of a semi-crystalline structure embedding cellulose molecular chains. In the crystalline domains, the long chains of cellulose are connected by hydrogen bonds and form a highly ordered crystalline structure. The amorphous region of cellulose in plants usually consists in hemicelluloses and lignin, and sometimes pectin. The properties of cellulose extracted from plants depend not only on the treatment methods applied, but also on the plant source and the plant part used. ${ }^{6,11-12}$ Depending on the synthesis approach, natural cellulose can be transformed into different nanostructures, such as crystals or fibrils (Fig. 2).

\section{Cellulose from microorganisms}

In addition to plants, several microorganisms can be used to produce cellulose, either in vivo or in vitro. ${ }^{14-15}$ For instance, cellulose has been found in some classes of green algae, such as Chlorophyceae, Valonia ventricosa (also known bubble algae), Chaetamorpha melagonicum, and Glaucocystis. Although the cell wall of most fungi consists of chitin, several fungi, namely, Acytostelium, Dictyostelium and Polysphondylium, have cellulose in their cell wall. Bacteria belonging to the genera Gluconacetobacter (or Acetobacter), Agrobacterium, Pseudomonas, Rhizobium and Sarcinacan can synthesize cellulose from the carbon sources (like glucose) existing in their culture media. Amongst the cellulose-forming bacteria, a non-pathogen, gram-negative bacterium Gluconoacetobacter, which secretes the cellulose into the culture medium, is suitable for economical production of bacterial cellulose. $^{16-18}$

Bacterial cellulose is a fibrous network with a high degree of polymerization (up to 10,000), as well as high crystallinity (70-80\%) and purity (no lignin, hemicelluloses, pectin, or other biogenic products). ${ }^{18-20}$ These characteristics make bacterial cellulose an appropriate material to be used in electronics, acoustics, and biomedical devices. Bacterial cellulose has been used to develop hydrogels, due to its large surface area and hydrophilic nature. However, due to its low compressive modulus, the water is easily squeezed out of the gel under slight compression. ${ }^{14}$ Despite all the exceptional features of bacterial cellulose, its production 
requires special care and handling to maintain optimal production.

\section{Animal cellulose}

Cellulose can be also found in the outer membranes of some marine animals, like Ascidians, known as tunicates or sea squirts. The cellulose that reinforces the proteins of the outer membrane of Ascidians can be obtained through bleaching treatments of the protein. ${ }^{21,22}$ The cellulose nanostructures derived from tunicates exhibited higher crystallinity and aspect ratio, compared to NC obtained from bacteria. ${ }^{8}$ However, cellulose from marine animals is of little commercial interest because of its lower availability.

\section{CRYSTALLINE STRUCTURE OF CELLULOSE}

Several polymorphs of cellulose are known to exist, called cellulose I, II, III and IV. They all differ in the dimension of the unit cells, number of chains included in the crystal unit cell, orientation of the chains in the crystal (parallel or antiparallel) and chain polarity. Almost all natural celluloses consist of cellulose I, which is a composite of two crystalline allomorphs, labeled as $\mathrm{I}_{\alpha}$ and $\mathrm{I}_{\beta} .{ }^{20}$ The conversion between these allomorphs generally occurs under hydrothermal conditions, when the hydrogen bonds between cellulose sheets are splitted. ${ }^{23,24}$

Table 1

Cellulose polymorphs and their characteristics

\begin{tabular}{|c|c|c|c|c|c|}
\hline \multirow{2}{*}{ 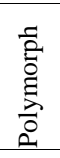 } & \multirow[b]{2}{*}{$\begin{array}{c}\text { Chain } \\
\text { characteristics }\end{array}$} & \multicolumn{2}{|c|}{$\mathrm{XRD}^{25-29}$} & \multirow{2}{*}{$\begin{array}{l}\text { FTIR }^{28-30} \\
\text { peaks at } \\
\left(\mathrm{cm}^{-1}\right)\end{array}$} & \multirow[b]{2}{*}{$\mathrm{NMR}^{29-31}$} \\
\hline & & $\begin{array}{l}\text { Bragg's } \\
\text { angle }\end{array}$ & $\begin{array}{l}\text { Miller } \\
\text { index }\end{array}$ & & \\
\hline $\mathrm{I}_{\alpha}$ & $\begin{array}{l}\text { One-chain } \\
\text { triclinic } \\
\text { Parallel }\end{array}$ & $\begin{array}{c}14.3-14.5 \\
16.3-16.9 \\
22.5-22.9 \\
34-34.4 \\
\end{array}$ & $\begin{array}{l}100 \\
010 \\
110 \\
11 \overline{4}\end{array}$ & $\begin{array}{c}750 \\
3240\end{array}$ & $\begin{array}{l}\text { Double peaks in C4 region } \\
\text { The } 2^{\text {nd }} \text { peak in the down-field site at } 89.7 \\
\text { ppm }\end{array}$ \\
\hline $\mathrm{I}_{\beta}$ & $\begin{array}{l}\text { Two-chain } \\
\text { triclinic } \\
\text { Parallel }\end{array}$ & $\begin{array}{l}14.5-14.9 \\
16.5-16.7 \\
22.5-23 \\
20.6 \\
34.5\end{array}$ & $\begin{array}{l}1 \overline{1} 0 \\
110 \\
200 \\
102 \\
004\end{array}$ & $\begin{array}{l}710 \\
3270 \\
3340\end{array}$ & $\begin{array}{l}\text { C-6 chemical shift at } 64.8-64.9 \mathrm{ppm} \\
\text { Double peaks in C4 region } \\
\text { The } 2^{\text {nd }} \text { peak in the up-field site at } 88 \mathrm{ppm} \\
\text { Double peaks in the C1 region around } 106 \\
\text { ppm }\end{array}$ \\
\hline II & $\begin{array}{l}\text { Two-chain } \\
\text { monoclinic } \\
\text { Antiparallel }\end{array}$ & $\begin{array}{c}12-12.2 \\
20 \\
21.8-22.1 \\
34-37 \\
\end{array}$ & $\begin{array}{l}1 \overline{1} 0 \\
110 \\
020 \\
004\end{array}$ & $\begin{array}{c}3450 \\
3480-3484\end{array}$ & $\begin{array}{l}\text { C- } 6 \text { chemical shift at } 62.2-62.8 \mathrm{ppm} \\
\text { Double peaks in the } \mathrm{C} 1 \text { region } \\
\text { Double peaks in the C } 4 \text { region }\end{array}$ \\
\hline $\mathrm{III}_{\mathrm{I}}$ & $\begin{array}{l}\text { One-chain } \\
\text { monoclinic } \\
\text { Parallel }\end{array}$ & $\begin{array}{c}11.7 \\
17.2-17.3 \\
20.7-21.1\end{array}$ & $\begin{array}{l}010 \\
002 \\
100 \\
012 \\
\overline{1} 10\end{array}$ & 3480 & C-6 chemical shift at $62.1-62.2 \mathrm{ppm}$ \\
\hline $\mathrm{III}_{\text {II }}$ & $\begin{array}{l}\text { Still being } \\
\text { debated } \\
\text { Antiparallel }\end{array}$ & $\begin{array}{c}11.7 \\
20.7-21.1\end{array}$ & $\begin{array}{l}010 \\
100 \\
012 \\
1 \overline{1} 0\end{array}$ & $\begin{array}{l}3450 \\
3480\end{array}$ & C-6 chemical shift at $62.4-62.5 \mathrm{ppm}$ \\
\hline $\mathrm{IV}_{\mathrm{I}}$ & $\begin{array}{c}\text { Disordered form } \\
\text { of cellulose I } \\
\text { Parallel } \\
\end{array}$ & $\mathrm{NR}^{*}$ & & & \\
\hline $\mathrm{IV}_{\mathrm{II}}$ & $\begin{array}{l}\text { Still being } \\
\text { debated } \\
\text { Antiparallel }\end{array}$ & $\begin{array}{c}15.5 \\
15.5 \\
20 \\
22 \\
35\end{array}$ & $\begin{array}{l}1 \overline{1} 0 \\
110 \\
012 \\
020 \\
004\end{array}$ & NR & C-6 chemical shift at $63-63.6 \mathrm{ppm}$ \\
\hline
\end{tabular}

* NR - not reported 
Cellulose obtained from algae (e.g. Valonia) and bacteria (e.g. G. xylinum) is predominantly cellulose $\mathrm{I}_{\alpha}$, whereas plant cellulose is mostly cellulose $\mathrm{I}_{\beta}$. The crystalline cellulose $\mathrm{I}_{\alpha}$ is thermodynamically metastable, while $\mathrm{I}_{\beta}$ is more stable. ${ }^{7}$ Partial conversion of cellulose $\mathrm{I}_{\alpha}$ to $\mathrm{I}_{\beta}$ happens by its annealing at a temperature higher than $250{ }^{\circ} \mathrm{C}$. This conversion is irreversible. ${ }^{20}$ Cellulose II is known as the most stable crystalline structure of cellulose.

It is formed naturally by a mutant strain of Gluconacetobacter xylinum and the alga Halicystis. Also, it can be obtained by the treatment of cellulose I via regeneration (dissolved and precipitated) and/or mercerization (treated with a strong alkaline swelling agent $(\sim 20 \%)$ and washed with water). ${ }^{7}$ The transformation of cellulose I to cellulose II is irreversible. Cellulose III, a fairly stable polymorph, is formed by treating cellulose I or II with liquid ammonia at a temperature below -30 ${ }^{\circ} \mathrm{C}$, or with amines, followed by removing the swelling agent anhydrously, for example, by washing with alcohol. Depending on the cellulose polymorph (I or II), two subclasses ( $\mathrm{III}_{\mathrm{I}}$ and $\mathrm{III}_{\mathrm{II}}$ ), with small differences in the lattice dimensions of the crystals, are formed. ${ }^{7}$ Cellulose IV is formed by annealing of cellulose III in a suitable liquid, for example glycerol, at high temperature and under tension. ${ }^{10}$ The structure of cellulose III II $_{\text {II }}$ and cellulose IV is still a matter of debate. Cellulose $\mathrm{IV}_{\mathrm{I}}$ is known as the disordered form of cellulose I.

Several characterization techniques have been used to study the crystalline structure at the subnanometer level. These techniques include neutron diffraction (ND), X-ray diffraction (XRD), infrared spectroscopy (FTIR), Raman spectroscopy, nuclear magnetic resonance (NMR), and vibrational sum frequency generation (SFG). Each technique can provide specific information that can be used for differentiation of the polymorphs. Table 1 presents information about the structure of the cellulose polymorphs and their characteristics obtained by XRD, FTIR or NMR methods. The final characteristics of cellulose nanostructures depend not only on the source of cellulose, but also on its treatment procedure or method of production. Common treatment techniques used for cellulose fibrillation will be presented in the following section.

\section{OVERVIEW OF SYNTHESIS METHODS}

Depending on the source of NC (plants, microorganism or animal), the synthesis approach is different. Due to their availability, plants are the most widely investigated source for NC production. The top-down approach, including mechanical, chemical and biochemical extraction procedures, has been used to produce NC from plant sources. Cellulose production from microorganisms and/or animals is a bottom-up approach, which has also attracted attention recently. Accordingly, this section focuses on NC production from plants and bacteria.

\section{Cellulose from plants - a top-down approach}

The amorphous and crystal parts of cellulose in plant cell walls are sequentially located along the fiber direction in a row. The amorphous parts can be easily broken, while breakage of the crystal parts is impossible due to the presence of strong hydrogen bonds between the hydroxyl groups in cellulose. The production of cellulose nanostructures from natural resources is not an easy task because there are a variety of plant sources with different composition. Depending on the synthesis approach, natural cellulose can be transformed into different nanostructures, such as crystals or fibrils. The production of cellulose nanostructures from plant sources, including wood, non-wood plants, agricultural crops, and agricultural wastes, is generally a multi-stage process. A pretreatment of natural sources is usually required to disrupt the lignin structure, delaminate the cell wall and obtain individual cellulosic fibers. Depending on the plant source of the cellulose, the pretreatment method, which facilitates access to the micro-sites of cellulose during the next stage, is selected. For instance, agricultural crops and by-products contain less lignin than wood. A proper selection of the pretreatment procedure will increase the accessibility to the micro-sites of cellulose, while maintaining a desired degree of its polymerization. Cellulosic fibers are further processed to break the amorphous parts of cellulose and extract the cellulose nanostructure. The size and type of the nanostructure formed, i.e. nanofiber, nanocrystal or nanowhisker, depends not only on the source of the cellulose, but also on the procedure used. There are three distinct approaches used in a route to extract cellulose nanostructures from plant sources: mechanical treatment, chemical treatments and biochemical treatment, which is enzymatic hydrolysis. A combination of these techniques is usually applied, improving the fibrillation and thus NC extraction. 


\section{Mechanical extraction methods}

Mechanical treatments that subject natural fibers to high shear forces enable cellulose fibrillation. Mechanical processes used to extract cellulose include mainly refining and highpressure homogenization, grinding, cryocrushing and high intensity ultrasonic treatments.

\section{Homogenization}

In a homogenizer, a dilute suspension of cellulose is pumped at high pressure through a spring-loaded valve to pass through a thin slit. The quick reciprocating motion of the valve subjects the fiber to a large pressure drop and high shearing forces. The degree of defibrillation directly depends on the pressure and number of recycles. Repeated high-pressure homogenization of diluted cellulose slurry promotes fibrillation of the cellulosic fibers. ${ }^{32,33}$ The pressure as well as homogenization cycles also influence the characteristics of cellulose nanostructures, including their diameter and crystallinity. ${ }^{34}$ The degree of cellulose defibrillation depends on the polarity and swelling properties of the liquid, which the cellulose fibers are dispersed in. Any polar liquid can be used to prepare the cellulose suspension; however, the aqueous suspension of cellulose is preferred. Besides the parameters mentioned, the dimension and design of the homogenizer chamber requires precise consideration. An important issue is the agglomeration of cellulose fiber that blocks the narrow slit in the device and leads to termination of the process. Besides that, because of the high pressure applied, the chamber must be strong enough to tolerate this level of pressure. Another problem is that an increasing suspension temperature in the homogenizer influences the process yield and product properties. Because of the high-energy consumption of the homogenization process, cellulose fibers are commonly pretreated by other techniques to reduce the energy consumption and promote the process efficiency. ${ }^{32,35-39}$

\section{Microfluidization}

In a microfluidizer, the cellulose slurry is continuously pumped into precisely engineered micro-channels within an interaction chamber. The slurry is fed through an intensifier pump, which supplies the desired pressure and pushes the sample at a constant rate into the interaction chamber. The micro-channels have a precisely defined fixed-geometry, commonly $\mathrm{Z}$ - or $\mathrm{Y}$ - shaped, which accelerate the slurry stream to high velocities and impose high shear (up to $10^{-7} \mathrm{~s}^{-1}$ ). The extremely high shear and impact forces will delaminate the cellulosic fiber to NC. The outlet stream is usually circulated through the chamber to improve the degree of fibrillation and obtain homogeneous particle size distribution.

The geometry of micro-channels, which influence the shear and forces produced, plays a key role in the efficiency of fibrillation and dispersive mixing of the cellulose fibers. Keep in mind that micro-fluids at such high velocity have a complex flow, where the shear rate, shear stress, and boundary conditions cannot be well defined. Consequently, the fluid properties, such as viscosity, and first normal stress difference cannot be assigned a value characteristic of the fluid. Like in the case of homogenization, a pretreatment is necessary in order to enhance fiber accessibility and processing efficiency. ${ }^{40-42}$

\section{Grinding process}

Grinding is the breakdown of cellulose fibers by applying mechanical shear stress. Two methods of grinding are distinguished: wet and dry grinding. In wet grinding, an aqueous suspension of cellulose fibers is subjected to mechanical shear, whereas in dry grinding no water is present. Dry grinding increases the biomass reactivity without any effluent production, however, its energy consumption for biomass grinding is a limiting factor to be employed at an industrial level. Wet grinding, which consumes less energy, also generates irreversible changes in the fibers, increasing their bonding potential by modification of their morphology and size. Different types of grinders have been employed in NC production. ${ }^{43-46}$ The most frequently used grinders are disc mills, planetary ball mills, bead mills, pearl mills, and twin-screw extruders. An ultrafine friction grinder, which is a specially designed disc mill, was predominately used to fibrillate a dilute slurry of cellulosic fibers. ${ }^{43,47}$ All these studies indicated that the size of NC depends on the round number and speed of grinding. However, after a maximum number of rounds, there is no significant change in the size of NC.

\section{Cryocrushing}

The slurry of cellulose fiber is frozen using liquid nitrogen or propane. The fibers are then subjected to high shear forces and the ice crystals formed within the cells exert pressure on the cell 
walls, causing them to rupture and release microfibrils. ${ }^{48-51}$

\section{Ultrasonication}

Ultrasonication is another mechanical method in which hydrodynamic forces disaggregate cellulosic fiber to nanofibers. In this method, ultrasonic waves (typically $20-50 \mathrm{kHz}$ ) in aqueous medium create strong mechanical stress because of cavitations and cause defibrillation of cellulose fibers. Ultrasonication is, basically, an assisted method, which is used in combination with chemical/biochemical processes and sometimes with other mechanical methods. ${ }^{9,52-58}$ These studies indicate that the application of ultrasonic waves helps produce cellulose nanostructures. The efficiency of defibrillation in the ultrasonication process depends on the power, concentration, temperature, time and distance from the probe tip used, as well as the dimensions of the source fibers. ${ }^{55}$ Besides its high level of noise and energy generation, free radicals that can react with other molecules may be generated when ultrasound is used to fibrillate the cellulose.

\section{Aqueous counter collision (ACC)}

In this technique, a pair of water jets is used to reduce the particle size of materials. The kinetic energy produced by this method can be in the range of $6.7-18.1 \mathrm{~kJ} / \mathrm{mol}$. This amount of energy is high enough to disturb the dipole-dipole, London dispersion forces, and weak hydrogen bonds. ${ }^{59-61}$ The characteristics of cellulose nanostructures, including their dimension and the type of crystals, vary as a function of treatment repetition. Research indicated that, by repetition of aqueous counter collision, cellulose $I_{\alpha}$ was converted to $I_{\beta}$, while it retained its high crystallinity. ${ }^{60}$

\section{Electrospinning}

Electrospinning is a method used to prepare cellulose nanostructures through the action of electrostatic forces. Under a voltage adequate to overcome surface tension forces, a jet of cellulose suspension shoots out toward a collector, where the interconnected nanofibers are collected. The effectiveness of this method in defibrillation of cellulose depends on its controlled swelling and dissolution in a liquid phase. In a suitable solvent or swelling agent, the crystalline cellulose can be separated efficiently into nanofibers. ${ }^{61-66}$

Several solvents have been investigated for cellulose, such as $\mathrm{N}, \mathrm{N}$-dimethylacetamide
(DMAc) with lithium chloride ( $\mathrm{LiCl}$ ) ${ }^{67}$ dimethyl sulfoxide (DMSO)/triethylamine/ $\mathrm{SO}_{2},{ }^{68} \mathrm{~N}$ methylmorpholine-N-oxide (NMMO) ${ }^{69}$ aqueous solution of $\mathrm{NaOH} / \mathrm{urea}^{70}$ and ionic liquids, like 1butyl-3-methylinmidazolium chloride (BMIMCl), 1-allyl-3-methylimidazolium chloride, 1-butyl-3methylimidazolium hydrogen sulfate or carbon disulfide/aqueous $\mathrm{NaOH}{ }^{64-66,71-75}$

Whereas the dissolution of cellulose is a key step in this method, an appropriate solvent to dissolve cellulose is difficult to find. In this respect, pretreatment of cellulose has been examined. For instance, since the derivatives of cellulose can be dissolved in many common solvents, especially organic solvents, chemical treatments to obtain a derivative of cellulose, such as cellulose acetate, carboxymethyl cellulose or hydroxypropyl methylcellulose, have been tried. Another approach is using enzymatic pretreatment of cellulose. ${ }^{61}$ The result of electrospinning depends not only on the type of solvent (single or binary solvent), but also on the spinning conditions, origin of cellulose, its degree of polymerization and pretreatment methods. ${ }^{76}$

\section{Steam explosion}

In this process, the biomass is subjected to high pressure steam (20 bar and higher) at temperature higher than $200{ }^{\circ} \mathrm{C}$ for a relatively short time. Depending on the degree of decomposition achieved though steam explosion, a post-treatment procedure to remove the remained hemicelluloses and lignin is necessary. The effectiveness of steam explosion depends upon the nature of the feedstock and the operation conditions, such as pressure, temperature and process time. $36,77-79$

\section{Chemical approaches}

There are various chemical approaches, such as acid hydrolysis, oxidation, carboxymethylation, acetylation, chlorination and alkaline treatment, used in a route to produce cellulose nanostructures. The aim of these approaches is different and can be either chemical modification of the cellulose surface, improvement of cellulose dispersion, breakage of bonds or removal of undesired components, such as lignin and hemicelluloses. $^{11,33,79-81}$

Among the mentioned approaches, acid hydrolysis has been widely used as acids can effectively break the amorphous region in natural fiber and release its crystal domains into the suspension. Depending on the plant source of 
fiber, hydrolysis conditions must be mild enough to avoid conversion of cellulose to glucose. Besides the source of cellulose, processing conditions influence both the process efficiency and product properties. ${ }^{12,38,82-88}$ The processing factors include the type of acid used, its strength, reaction time, temperature and the ratio of acid to cellulose. The mostly used acids have been sulfuric and hydrochloric acids, however, using other acids, such as phosphoric, ${ }^{81-83}$ hydrobromic $^{92-93}$ and organic acids (like maleic acid), ${ }^{94}$ have been reported. Although all acids can hydrolyze the amorphous domain, they have different power of hydrolysis and they can affect the properties of the reaction environment, as well as the product. $^{89}$ In this respect, acid mixtures have been also examined to improve the process results. ${ }^{95-96}$ Solid acid catalysts, with Brønsted acid active sites, can be used in the hydrolysis reaction, instead of concentrated acids. However, the contact between the catalyst active sites and cellulose are challenging as both the reactant and the catalyst are in solid phase. Similarly to acids, ionic liquids, introduced as solubilizing agents for cellulose, can also break the glycosidic bonds between the anhydroglucose units in cellulose. ${ }^{73,97}$ Since ionic liquids are not consumed and can be regenerated at the end of the reaction, it is logical to say they act as catalyst.

Oxidation of native cellulose, with the purpose of its surface modification, has been mostly used as a pretreatment step in a route to produce nanocellulose. ${ }^{57,98-101}$ This pretreatment leads to saving energy consumption, especially where the mechanical approach is used to produce nanocellulose. The most used oxidation of native cellulose is catalytic oxidation using TEMPO (2,2,6,6-tetramethylpiperidine-1-oxyl). TEMPO oxidation consists in a selective conversion of the hydroxyl groups in native cellulose to aldehyde and carboxylate functional groups in the aqueous phase and under mild conditions. In TEMPO oxidation, fibers are separated due to the repulsive forces among ionized carboxylates, which overwhelm the hydrogen bonds holding them together. $^{102}$

Among the chemical approaches introduced here, acid hydrolysis and TEMPO oxidation are toxic and environmentally incompatible processes, while using ionic liquids facilitates sustainable and green production of nanocellulose.

\section{Biochemical approach}

Similarly to chemical hydrolysis, cellulolytic enzymes (specifically, endoglucanase) attack the amorphous regions of the cellulose fibers and make the extraction of $\mathrm{NC}$ easier. The major advantage of the enzymatic treatment for NC production, compared to other techniques, is the selective hydrolysis of the amorphous region. This selective hydrolysis caused the cellulose nanostructures produced to have a more favorable structure than those produced by chemical hydrolysis. ${ }^{42}$ Other advantages of biochemical hydrolysis from the environmental point of view are related to that fact that it is less corrosive, involves less loss of material and requires low energy consumption. The immobilization of enzyme can be performed to improve the enzymatic hydrolysis economically. However, the low yield and high cost of enzymatic hydrolysis are important issues that limit its industrial application. ${ }^{2,8}$ In almost all the studies that used enzymatic hydrolysis to produce nanocellulose, this treatment is combined with other methods, mechanical or chemical ones. ${ }^{2,35,41,48,103-104}$

It is worth mentioning that biochemical treatment must be performed in very aseptic conditions and thus some technical considerations, such as sterilization of the equipment and protection against contaminants, must be taken into account.

\section{Synthesis of bacterial cellulose}

Bacterial NC is produced by Gluconacetobacter as a part of its carbon metabolism. In addition to glucose and fructose, other carbohydrates, such as manitol, glycerol, sucrose and galactose, can be used as carbon sources in Gluconacetobacter culture. ${ }^{105}$ Depending on the main carbon source in the growth medium, there are different initial pathways toward the central metabolites. Different pathways produce different amounts of water-soluble polysaccharides, like acetan and levan, which influence the production of cellulose nanostructures. ${ }^{106}$ The amount of these watersoluble polysaccharides produced depends on the type of carbon source and bacterial strain, as well as whether the strain is mutant or wild type.

Two production methods, static and agitated, in different cultivation approaches (batch, fedbatch, continuous) have been used to produce bacterial NC. 
In the static method, a gelatinous layer (up to several centimeters thick) is formed on the surface of the incubation medium, whereas in the agitated culture, irregular spherical grains are obtained. ${ }^{107}$ Accordingly, depending on the desired application of cellulose, the cultivation method is selected.

Despite many attempts for the production of bacterial NC, its commercial production is still performed through static cultivation in shallow containers, using minimally automated work processes. For transferring the production of bacterial NC to an industrial scale, the yield and efficiency of the process need to be significantly improved. In this respect, novel and modified bioreactors have been designed. As an example, Song et al. $^{108}$ modified the airlift-type bubble column bioreactor or Kralisch et al. ${ }^{109}$ developed a horizontal lift reactor.

Whether the static or agitated production method is used, the applied conditions influence the properties of the obtained nanocellulose, its yield and rate of production. ${ }^{105-106,110-115}$ The production conditions include carbon source and its concentration, process temperature, oxygen supply, and process time. It is worth mentioning that the efficiency of the process, when it involves microorganisms, also depends on how well the equipment is sterilized and protected against contaminants.

\section{PROPERTIES AND APPLICATIONS OF CELLULOSE NANOSTRUCTURES}

Nanocellulose, which is smooth, transparent, mechanically strong and thermally resistant, allows creating durable and flexible paper-based energy devices. ${ }^{116}$ It contains three hydroxyl groups, which are highly active and useful for chemical modification. ${ }^{10}$ This section explains how these characteristics are involved in developing paper-based energy devices. Minimization of thermal effects on the device is one of the main requirements for its performance. Thermal stability of the materials determines the temperature range for material processing, as well as the final characteristics of the product and its usage. For instance, melt processing requires high temperatures, and hence this method cannot be applied for materials with low thermal stability. Smart devices and sensors also require reliable thermal isolation between the sensing elements and the sensor substrate. Besides, poor thermal stability limits the layer thickness of the paper, while the paper thickness affects the performance of the device. Thin and strong papers are suitable to be used not only as a reinforcement element, but also as a binding material in energy storage applications. For instance, a thin separator is preferred for supercapacitors, as it provides the maximum capacitance for them. ${ }^{117}$ It is worth mentioning that the thermal characteristics of nanocomposites depend not only on the nanocellulose, but also on the other components (especially the polymer), as well as on good dispersion of nanocellulose and its compatibility with the other components.

Cellulose nanocrystals exhibit a very low thermal expansion coefficient (TEC), ranging from $0.5 \times 10^{-5} \mathrm{~K}^{-1}$ to $17 \times 10^{-5} \mathrm{~K}^{-1}$, depending on their polymorphism and surface chemistry. ${ }^{118}$ It has been reported that, unlike the cellulose nanocrystals, which showed a linear TEC, the composite containing nanocellulose exhibited almost no thermal expansion or contraction. The TEC for the nanocomposite made of nanocellulose was reported lower than that for cellulose nanocrystals (about $10^{-7} \mathrm{~K}^{-1}$ ). ${ }^{118}$ This value is lower than the TEC of metals, which is about $\sim 10^{-6} \mathrm{~K}^{-1}$. Because of the low TEC of nanocellulose, paper-based energy devices exhibit high resistance to thermal shock and thermal deformation. The strength of interactions in the polymer-nanocellulose network needs to be strong enough to restrict the TEC of the composites.

Besides their favorable thermal properties, cellulose nanostructures indicate good mechanical properties, which make them suitable to be used in paper-based energy storage devices. For example, strong porous films using nanocellulose, in which hydrogen bonds generate inter-fiber contacts, can be fabricated. ${ }^{116}$ This porous structure allows the ionic species move easily between the electrode surfaces. High elastic modulus (up to $150 \mathrm{GPa}$ ) and strength (up to 7 GPa) have been reported for nanocellulose. ${ }^{118}$ Different values have been reported for the stiffness of nanocellulose, depending on its original source, morphological properties, geometrical dimensions, degree of crystallinity and polymorphism. Besides these inherent characteristics of nanocelluose, the method applied for its production, as well as the measurement method used, caused differences in the reported data.

Interestingly, nanocellulose exhibits different optical response, compared to other cellulosic materials, because of its nanoscale size, anisotropic individual structures and liquid 
crystalline behavior. ${ }^{118}$ Cellulose nanocrystals are birefringent, and have refractive indices of 1.618 and 1.544 in the axial and transverse directions, respectively. The optical properties of transparent cellulosic films can be tuned by modifying the precursor liquid crystalline characteristics of the system, as well as by varying the amount of the nanocellulose. Well-dispersed nanocellulose can replace conventional co-binding materials in coatings to improve whiteness, opacity, smoothness, and printing clarity of new papers. Environmentally friendly transparent films made of nanocellulose are a good substitute for transparent plastics in different devices, for example, flexible displays, organic light emitting diodes, transparent insulating, or semiconducting substrates in transparent paper transistors. Paperbased transistors are applicable in disposable microelectronics, such as biosensors, and in intelligent packaging.

\section{PAPER-BASED ENERGY DEVICES IN ENERGY APPLICATIONS}

Nanocellulose has been proposed to be used in paper-based devices due to its outstanding properties. ${ }^{5,40,116,119-121}$ The three-dimensional hierarchical structure of nanocellulose and its ability to hold other functional materials open up great opportunities for using cellulose in electrical, electrochemical, optical and energy storage devices. ${ }^{5}$ Paper is generally known as an insulating material. However, it is possible to make it conductive by incorporation of conducting materials, such as metals, or carbon nanostructures (carbon nanotubes or graphene). ${ }^{120,122-124}$

Conductive papers are fabricated by two different approaches: one in which cellulose is the host-matrix for additives and the other where, besides additives, cellulose is blended with another polymer. Conductive papers have high flexibility, which makes them suitable for applications where high load or high frequency exists. However, the applications of cellulose are restricted because of its limited functionalities. On the other hand, cellulosic nanostructures, with their exceptional properties (including high aspect ratio, very low density, high thermal stability, chemical resistance, and high mechanical strength), have broadened the development of conductive papers for different applications. Besides, the similarity in dimensions of NC and other nanostructures, such as CNTs, graphene and $\mathrm{Cu}$ nanoparticles, allows uniform mixing of the two components in a matrix, which results in highly conductive films. Such films are appropriate for various applications, ranging from energy-efficient devices to smart devices and electronic components (like transistors). ${ }^{5,119-120,125-}$ ${ }^{127}$ The low density of nanocellulose also encourages its usage in the fabrication of portable electronic devices.

\section{Energy storage devices}

Energy-efficient devices, in which excess energy can be held for future usage, are now the center of attention. The performance of such devices depends on how the energy is stored. Cellulose, due to its extraordinary structure, is a promising candidate to be used in energy storage systems. The linear chains of plant cellulose aggregate to highly ordered structures, which are fibers at the nanoscale, called nanofibrils. These structured nanofibers are suitable in the fabrication of energy storage devices.

According to the basic operating principles, paper-based devices for energy storage could be categorized as: (i) electrochemical devices, including batteries (in lithium-ion batteries) and electrochemical capacitors (or supercapacitors), (ii) fuel cells and (iii) nanogenerators.

Electrochemical batteries and electrochemical capacitors are two types of energy storage devices that work based on electrochemical processes. They have similar structure, consisting of two electrodes, an electrolyte and a separator. The electrodes are conductive for transporting electrons and ions, and the separator electrically isolates the two electrodes. However, despite their structural similarity, they use different storage mechanisms. In batteries, the electric charge is stored as chemical energy through an electrochemical redox reaction, whereas in supercapacitors the electrostatic charge is stored through the formation of an electric double layer at the interface between the electrolyte and the electrodes. This difference makes their application different. The battery is generally taken if a large amount of energy is required to be delivered gradually. Whereas, if a powerful burst of energy lasting a short time is needed, the capacitor is used. Supercapacitors are employed in high power applications and batteries in low power applications.

Supercapacitors, due to their high specific capacitance and power density, are typically superior to batteries in the rate of charge/discharge, as well as with regard to their 
environmental impact and safety. With respect to the weight and volume of the devices, Li-ion batteries have much higher energy densities than supercapacitors. Consequently, Li-ion batteries have found by far the most application markets. ${ }^{119}$ However, there is a great attempt to enhance the performance of supercapacitors for a wider range of applications. For instance, to make supercapacitors flexible and stretchable, so that they can be used in portable and wearable electronics. ${ }^{125-129}$ Flexible supercapacitors, due to their high capability, long cycle life, low cost, and easy fabrication, have attracted great attention. Paper-based supercapacitors display much higher specific capacitances than devices based on plastic substrates, as well as excellent cycling performance. Wearable electronics (or smart textiles) are employed in several novel applications, such as high-performance sportswear, wearable displays, new classes of portable power, and embedded health monitoring devices. ${ }^{130-133}$ In all these applications, the device is expected to function steadily and hence it must be powered by stable and lasting energy sources. A current approach in fabricating wearable electronics is to create flexible batteries or supercapacitors integrated within a textile matrix. $^{133}$

Conductive papers, which are flexible and porous, are researched for fabricating energy storage devices. ${ }^{119,121,124-125,127-135}$ In both batteries and supercapacitors, cellulose nanostructures have been investigated to be used as electrodes, ${ }^{119,134,136}$ separators, ${ }^{134}$ and/or electrolytes. ${ }^{129,137,138}$ Conductive papers used as electrodes in energy storage devices showed higher rates of electron transfer, compared to conventional powder and film electrodes. The porous structure of conductive papers provides a desirable surface area that can achieve larger energy and power densities, higher rate capability and longer cycle life. It has been revealed that as the electrode thickness increases, the impedance associated with the ion or electron transport also increases dramatically. ${ }^{119}$ Therefore, larger internal resistance and potential are generated. These parameters are detrimental to the device efficiency and its stability performance. If cellulosic nanofibers are used in separators of batteries, as they provide a nanoporous structure, the ionic conductivity of a membrane soaked with liquid electrolyte increases. The main advantage of using cellulose nanostructures in fabricating energy storage devices is that they can serve as both electrode materials and separators, which results in developing flexible and thin devices. In such systems, electrodes and electrolytes are integrated into the paper.

Due to their large surface areas and high conductivity, CNTs have been explored as attractive supercapacitor materials, using the electrochemical double layer mechanism. ${ }^{119}$ However, unmodified CNTs are hydrophobic, and their applications in supercapacitors have been hindered by poor electrolyte wetting. ${ }^{124}$ Cellulose is highly water absorbent, which encourages the usage of conductive paper as electrodes for supercapacitors with aqueous electrolytes. By using cellulose, the aqueous electrolyte can be readily absorbed into the electrode and provides intimate contact between the electrode and the electrolyte.

In fuel cells, the chemical energy of a substrate, called fuel, is directly converted into electrical energy through an oxidation reaction between the fuel and an oxidant. Renewable fuels, such as hydrogen, ethanol, methane, etc., can be used in fuel cells to produce electricity. A biofuel cell is a specific type of fuel cell that uses a biocatalyst (enzyme) or microorganisms to oxidize organic fuels, such as glucose, biomass, wastewater, etc. Biofuel cells are a clean energy alternative to both electrochemical batteries and conventional fuel cells that use expensive metal catalysts. Another advantage of biofuel cells is that they operate under mild $\mathrm{pH}$ and temperature conditions, compared to conventional fuel cells.

Fraiwan et al. reported on the first paper-based microbial fuel cells. ${ }^{139,140}$ Rapid generation of electricity was observed, while conventional MFCs require long start-up times (typically several days to a week). This observation is attributed to the hydrophilicity of the cell, which provides accumulation and acclimation of bacteria on the MFC anode. ${ }^{139}$ Lee and Choi developed a 3-D paper-based bacteria-powered battery. ${ }^{121}$ They claimed that this battery can offer on-board energy to the next generation of paper-based systems with one drop of liquid derived from contaminant water and/or wastewater sources. Paper-based biofuel cells are a easy-to-use power source. However, their low power generation and short-term stability make them be preferred only for low power and/or single use applications. For instance, they are a perfect power source for paper diagnostic devices. The papers used in the biofuel cells also require to be sophisticatedly patterned for microfluidic channels. Figure 3 illustrates the 
fully assembled paper-based MFC and its different layers.

Nanogenerators can convert a tiny scale of mechanical energy received into electricity. For example, they can generate electricity from a gentle airflow or human activity (like walking, reading, typing, etc.). ${ }^{135}$ One marvelous application of nanogenerators is fabricating selfpowered systems and active sensors. ${ }^{141}$ Paperbased nanogenerators (PNG) are attractive for building low-cost, green and disposable selfpowered devices and systems. ${ }^{141,143}$ PNGs work based on the electrostatic effect. The electrostatic charges on the paper are generated by the corona method. ${ }^{142}$ Zhong et al. indicated that at a voltage of $110 \mathrm{~V}$, the instantaneous output power density of a single-layered PNG can reach nearly 91 $\mu \mathrm{Wcm}^{-2}{ }^{142}$ This power is sufficient to illuminate 70 LEDs instantaneously. They also fixed the PNG to a book and the energy of turning the pages lighted up two blue LEDs connected in antiparallel configuration. Kim et al. ${ }^{141}$ fabricated a foldable and thermally stable paper nanogenerator that included piezoelectrically active $\mathrm{ZnO}$ nanorods (Fig. 4 a). This paper-based nanogenerator was more thermally stable than the nanogenerator fabricated using polyethylene naphthalate (Fig. 4 b, c).

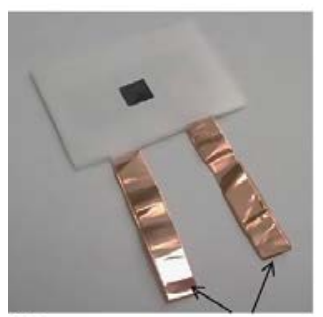

(a)
External electric contacts

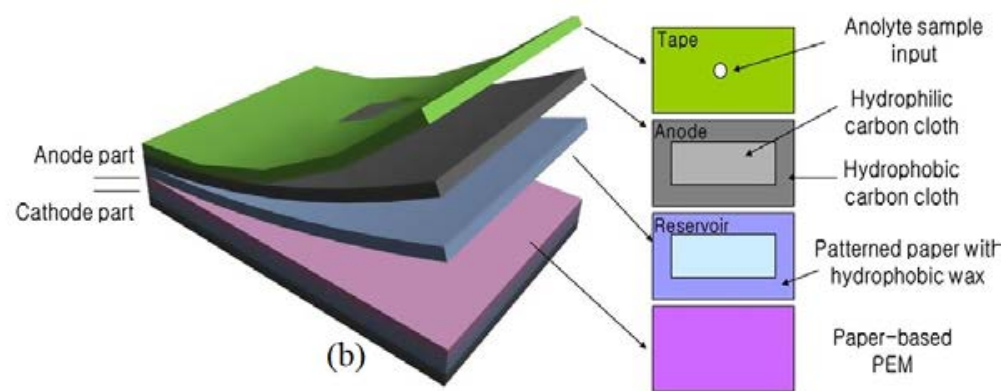

; (b) Different layers in paper-based MFC

Figure 3: (a) A photograph of fully assembled paper-based MFC;
(with permission)

(a)
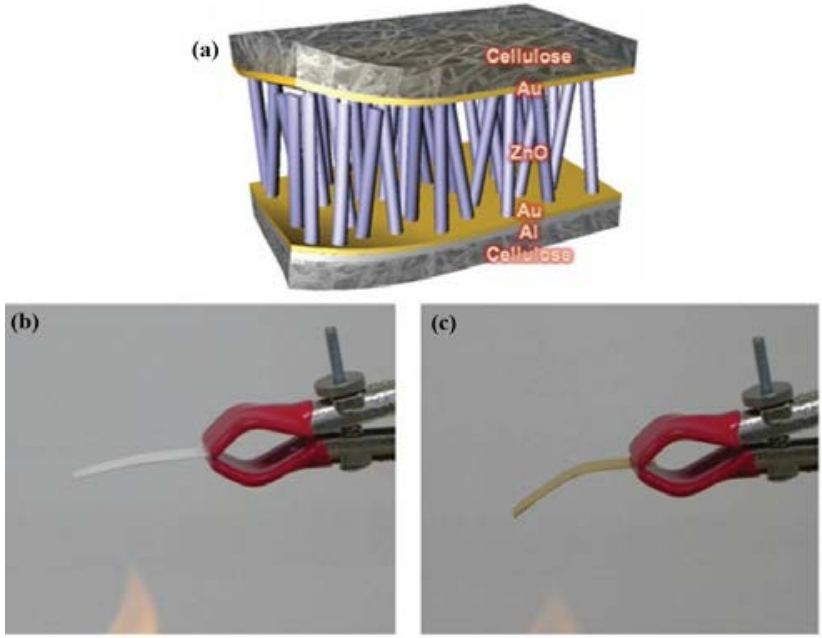

Figure 4: (a) A depiction of a paper-based generator with $\mathrm{ZnO}$ nanorods on a foldable cellulose paper; (b) A paperbased nanogenerator; (c) A polyethylene naphthalate nanogenerator (with permission) ${ }^{141}$

\section{Smart materials (sensors and actuators)}

A sensor is a type of electronic device applied for detecting some kind of stimulus instantaneously. The stimulus may be a change of temperature, $\mathrm{pH}$, light, pressure, humidity and/or chemical or biological compounds. Sensors are broadly utilized in our daily life, ranging from lab-on-a-chip devices to condition monitoring of appliances and protection of natural and synthetic environments. A sensor is fundamentally a transducer that generates a measurable response proportional to a change in a physical, chemical, 
or biological condition. A sensor is composed of two main parts: a receptor and a transducer. Receptors can detect any stimulus, while transducers change the stimulus to an electric signal.

The most important properties of a sensor include its sensitivity, selectivity, reproducibility, stability, linearity, and scalability. Other characteristics of a sensor, such as response time, spatial and temporal resolution, hysteresis, creep and aging, are also considered. Most of the properties named here depend on the characteristics of the material used in sensors. Accordingly, an appropriate selection of the sensing material is a prerequisite for the desired performance of a sensor. Sensors are basically fabricated using two different sources of materials: inorganic semiconductors, usually metal oxides, or organic conducting polymers. However, both materials have some advantages and limitations. Inorganic semiconductors are generally unstable because of the ionic conducting charge on the surface. Their working temperature is high, which results in high energy consumption and latent safety concerns. ${ }^{94}$ Organic materials that have a free electron on their double bond along the polymer main chain are appropriate for applications at ambient temperatures. However, they are not thermally stable and show very long response time. ${ }^{94}$ To resolve the limitations and drawbacks of each material, various research has been conducted to enhance the sensor ability and flexibility. Conductive composites are now extensively under study to optimize their characteristics in terms of both sensing ability and intrinsic properties, importantly mechanical and thermal stability. Conductive polymers filled with NC show higher elongation at break, tensile modulus, and strength than unfilled films.

Conductive papers, also called "smart papers" have recently attracted great interest to be used as an active material in sensors and actuators. ${ }^{5,102,144-}$ 151 Similarly to sensors, an actuator is also a transducer, but it works differently. Actuators accept an electrical signal and take physical action. Smart papers have indicated good mechanically adaptive behavior in response to different stimuli. A promising characteristic of smart papers used as active sensors is that they are self-powered systems. ${ }^{139,142,152-153}$

Yan and co-authors have developed smart papers to be used in strain sensors, where resistance varies with any mechanical stimulus, like force, pressure, tension, weight, etc. ${ }^{154-155}$ Such sensors have broad applications in mobile health monitoring, robotics and vibration control applications. The reason is they can be integrated into micro-electromechanical systems (MEMS) or be used in other electric devices, like microactuators. Smart papers have been also successfully applied in controlled drug delivery systems, where an electro-stimulated targeted system is used, ${ }^{156-158}$ or as a biosensor in detection systems. ${ }^{159,160}$ Other examples of smart paper used in sensing applications include humidity sensors, ${ }^{161}$ detecting explosives in aqueous solution, ${ }^{152}$ piezoelectric sensors, ${ }^{162}$ and tracing heavy metals or pollutants. ${ }^{163}$

\section{Transparent sheets}

Generally, cellulose-based products are opaque; however, nanocellulose-based papers are transparent. ${ }^{33,122,124,164-169}$ Nanocellulose, due to its diameters being less than one-tenth of the visible light wavelength, avoid light scattering and, if the they packed densely, the tiny interstices between the nanoelements also avoid light scattering, and thus the cellulosic material becomes transparent. These outstanding characteristics offer the possibility of obtaining paper-based materials with high transparency and thermal stability similar to those of glass, while being lightweight and flexible as regular paper.

Tin-doped indium oxide (ITO) is generally used as a transparent electrode for optoelectronics. However, it is not mechanically resistant and easily cracks, which causes the malfunction of devices. ${ }^{119}$

Researchers are seeking to fabricate stronger and flexible transparent electrodes by using nanostructures. The low thermal expansion of transparent papers, with their high strength and modulus, combined with their flexibility, make them perfect for fabricating flexible transparent electronics and optoelectronics devices. Such devices, in which roll-to-roll processing is used, include conductive transparent electrodes for solar cells, display devices and organic light-emitting diodes (OLEDs).

It is worth mentioning that the optical properties of a paper-based electrode, including ISO brightness and opacity, as well as specific scattering, depend not only on the dimensions of the cellulose nanostructures, their morphology and crystallinity, but also on the method they are packed. ${ }^{124}$ 


\section{Insulation materials}

Cellulose-based materials were once traditionally used as insulating cover for electrical components, like cables and capacitors. However, because of the hygroscopicity and poor mechanical resistance of cellulosic coatings, plastic materials have replaced them. The hygroscopic and mechanical properties of cellulosic materials depend on both the degree of cellulose crystallinity and its porosity. ${ }^{170}$ The higher the degree of crystallinity and the porosity of cellulose, the less water sorption is observed. The water sorption properties of a paper-based component significantly affect its characteristics. ${ }^{171-172}$ The hydrophilic nature of NC can also be regulated by chemical modification or functionalization of the nanocelluloses. Some techniques that can reduce the hygroscopicity of the cellulosic material are graft polymerization, free radical polymerization, ${ }^{173,174}$ alkylation, acetylation, ${ }^{168}$ carbanylation, ${ }^{175}$ esterification, ${ }^{178}$ using a hydrophobic coating of the paper, ${ }^{177}$ and adsorption of cationic surfactants. ${ }^{101}$ The dielectric properties of a cellulosic compound also depend on other factors, including impurities, the content of hemicelluloses and lignin, the degree of polymerization, fiber length, and density. ${ }^{171}$

Oil impregnated paper is a reliable electrically insulating material in high voltage, high-power applications. Besides the cellulose availability and its low cost, the traditional exploitation of oilimpregnated paper is justified by some of its properties, such as high resistivity $\left(\sim 10^{10} \Omega \mathrm{cm}^{-1}\right)$, high electrical strength $\left(\sim 180 \mathrm{kV} \mathrm{cm}{ }^{-1}\right.$ in oil), chemical stability, flexibility and nonthermoplastic properties. ${ }^{171}$ Improved mechanical characteristics of paper make it suitable for longterm use in electrical transformers, which is still in demand. The insulating property of paper should be considered not only for its use in electronics and electrical applications. Due to its transparency, paper-based coatings can have an outstanding application as thermal and/or sound insulators. It is expected that such a transparent coating on a window can not only save energy, but also act as a sound insulator for the building. Table 2 summarizes the reported data about the paper-based energy storage devices in the literature. The data include the source of the cellulose used, the composition of nanocomposites, the preparation method and application.

\section{CHALLENGES AND FUTURE PROSPECTS}

Nowadays, NC is considered a most promising green material and a future alternative for replacing the currently used synthetic materials. However, there are some challenges in the way of commercialization of paper-based devices. These challenges are related to the production of nanocellulose and the fabrication of paper-based devices, as described below.

The most important issue is designing an economical and sustainable process for continuous and large-scale production of nanocellulose. In this way, regulation and standardization of the product and production method are essential.

In addition to the production issues, the performance of electronic and electrical paperbased energy devices strongly depends on the controlled structure of the NC produced. There is a direct relationship between the structure, porosity, dimensions and surface properties of the nanocellulose and its behaviors. Accordingly, controlling these characteristics is crucial for obtaining the advantage of using nanocellulosebased components in high-performance energy storage devices. Controlling the size, morphology and polymorphism of cellulose during production and treatment is challenging, because it relies on deep understanding of the NC structure at atom scale.

More challenges are related to the fabrication of paper-based devices. It is quite challenging to fabricate thin, lightweight and flexible paperbased devices, while preserving their high mechanical strength and appropriate electronic characteristics. Great efforts are conducting to resolving the mentioned problems, in parallel to designing and fabricating novel products, such as hierarchical 3D fibrous porous components, miniaturized analytical platforms, optical sensingbased electronics and wearable electronic devices. The future prospect of such efforts is paving the path for developing commercial applications of paper-based devices. 
Table 2

Paper-based energy storage devices reported in the literature

\begin{tabular}{|c|c|c|c|c|}
\hline Type of cellulose & Product composition & Preparation method & Application & Ref. \\
\hline $\begin{array}{l}\text { Soft wood kraft } \\
\text { pulp }\end{array}$ & $\begin{array}{l}\text { TEMPO-oxidized cellulose } \\
\text { nanofibrils (TOCN) }\end{array}$ & $\begin{array}{l}\text { Cast coating of } \\
\text { CNT/TOCN }\end{array}$ & $\begin{array}{l}\text { Touch panel and } \\
\text { printed electronic } \\
\text { application }\end{array}$ & 122 \\
\hline Cellulose & Cellulose/CNT & Printing & $\begin{array}{l}\text { Batteries and } \\
\text { supercapacitors }\end{array}$ & 134 \\
\hline $\begin{array}{l}\text { Cladophora } \\
\text { cellulose }\end{array}$ & $\begin{array}{l}\text { Polypyrrole/nanocellulose/ } \\
\text { carbon fiber }\end{array}$ & Moulding & $\begin{array}{c}\text { Storage devices for } \\
\text { high-power } \\
\text { applications }\end{array}$ & 136 \\
\hline $\begin{array}{l}\text { Bleached } \\
\text { cellulose fiber }\end{array}$ & $\begin{array}{l}\text { Carbon/impregnated paper with } \\
\text { sodium polysterene sulfonate }\end{array}$ & Sandwiching & Microbial fuel cells & 139 \\
\hline Paper & $\begin{array}{l}\text { Metal ( } \mathrm{ZnO}, \mathrm{Au}, \mathrm{Al}) \text { coated } \\
\text { cellulose }\end{array}$ & Spin coating & Nanogenerators & 141 \\
\hline Paper & Polyterauoroethylene-Ag-paper & $\begin{array}{l}\text { Thermal evaporation/ } \\
\text { spin coating }\end{array}$ & Nanogenerators & 142 \\
\hline Cellulose & $\begin{array}{c}\text { Transparent paper/polystryrene } \\
\text { sulfonate/ polylactic acid }\end{array}$ & Spin coating & Nanogenerators & 143 \\
\hline Filter paper & $\begin{array}{l}\text { Glassy carbon/ethylene } \\
\text { dioxythiophene }\end{array}$ & $\begin{array}{c}\text { Electro- } \\
\text { polymerization }\end{array}$ & $\begin{array}{l}\text { Microfluidic } \\
\text { sampling }\end{array}$ & 145 \\
\hline $\begin{array}{l}\text { Cladophora } \\
\text { cellulose }\end{array}$ & Polyanaline/cellulose & $\begin{array}{l}\text { Blending/sonication/ } \\
\text { filtering/drying }\end{array}$ & Lead II sensor & 146 \\
\hline $\begin{array}{l}\text { Commercial } \\
\text { nanocellulose }\end{array}$ & Graphene/nanocellulose & NR & Strain sensor & 154 \\
\hline Cotton fiber & $\begin{array}{l}\text { Carbon black/natural } \\
\text { rubber/nanocellulose }\end{array}$ & Blending/casting & Strain sensor & 155 \\
\hline $\begin{array}{l}\text { Microcrystalline } \\
\text { cellulose }\end{array}$ & $\begin{array}{l}\text { Cellulose nanocrystal/ } \\
\text { graphene oxide }\end{array}$ & Blending/oven drying & Humidity sensor & 161 \\
\hline $\begin{array}{l}\text { Bacterial } \\
\text { cellulose }\end{array}$ & $\begin{array}{l}\text { Silver coated polyethylene } \\
\text { terephthalate/bacterial cellulose }\end{array}$ & Sandwiching & Piezoelectric sensor & 162 \\
\hline $\begin{array}{l}\text { Bleached } \\
\text { softwood pulp }\end{array}$ & $\begin{array}{c}\text { Cyanobacterial } \\
\text { C-phycocyanin/nanocellulose }\end{array}$ & Immobilization & Copper, iron sensor & 163 \\
\hline Pure cotton pulp & $\begin{array}{l}\text { Modified graphene oxide/ } \\
\text { cellulose nanocrystal }\end{array}$ & $\begin{array}{l}\text { Layer-by-layer } \\
\text { spraying }\end{array}$ & Proximity sensor & 164 \\
\hline $\begin{array}{l}\text { Bleached } \\
\text { sulphite } \\
\text { softwood pulp }\end{array}$ & $\begin{array}{c}\text { Cladophora } \\
\text { cellulose/nanocellulose }\end{array}$ & Blending/drying & Electrical insulator & 171 \\
\hline $\begin{array}{l}\text { Commercial } \\
\text { nanocellulose }\end{array}$ & Nanocellulose/paper & Blending/hot pressing & Electrical insulator & 172 \\
\hline
\end{tabular}

\section{CONCLUSION}

Cellulose is widely distributed in plants and, to a lesser degree, in invertebrates and microorganisms. Cellulose derived from invertebrates and bacteria is free from lignin, pectin and hemicelluloses, which are commonly present in the cellulose extracted from plants. However, the cost of the cellulose obtained from bacteria or invertebrates is quite high, thus limiting its applications.

Plant NC is obtained via different methods of mechanical, chemical and biochemical treatments. The mechanical and biochemical treatments to produce NC are more sustainable than chemical treatments. However, biochemical methods are restricted by the high cost of enzymes, while mechanical methods are confined by their highenergy consumption. Accordingly, a combination of treatments is suggested for commercial production of NC.

Due to its outstanding properties, NC has been widely considered for the development of highperformance energy devices, including batteries, supercapacitors, nanogenerators, sensors and transducers, as well as 3D energy textiles. These energy devices have demonstrated superior performance and unique properties, such as being stretchable and flexible, compared to equivalent traditional conductors. Such marvelous 
characteristics of these devices are strongly linked to the unique properties of the paper or textile used. Consequently, cellulose nanostructures provide new functionalities that bring a great opportunity for paper producers to develop new value-added products. Nevertheless, there are some challenges in the way of commercialization of paper-based electronic and electrical devices, in which NC is used. The most important one is the industrial scale NC production, ensuring the robustness and scalability of the process for mass production of NC. Besides, regulation and standardization of the product are essential for commercialization of the NC applications. In addition to the production issues, the performance of electronic and electrical paper-based energy devices strongly depends on the controlled structures of the NC produced. In other words, protecting the morphology and polymorphism of cellulose during treatment is challenging, which triggers further investigations.

\section{REFERENCES}

1 Report "Cellulose Fiber Market", https://www.marketsandmarkets.com/PressReleases/ce llulose-fiber.asp

2 J. Y. R. Zhu, R. Sabo and X. Luo, Green Chem., 13, 1339 (2011), http://dx.doi.org/10.1039/c1gc15103g 3 J. Sadhukhan, J. R. Lloyd, K. Scott, G. C. Premier, H. Y. Eileen et al., Renew. Sustain. Energ. Rev., 56, 116 (2016), https://doi.org/10.1016/j.rser.2015.11.015

4 G. P. Robertson, S. K. Hamilton, B. L. Barham, B. E. Dale, R. C. Izaurralde et al., Science, 356, 2324 (2017), https://doi.org/10.1126/science.aal2324

D. Tobjörk and R. Österbacka, Adv. Mater., 23, 1935 (2011), https://doi.org/10.1016/j.cep.2012.07.007

6 L. Brinchi, F. Cotana, E. Fortunati and J. M. Kenny, Carbohyd. Polym., 94, 154 (2013), https://doi.org/10.1016/j.carbpol.2013.01.033

J. L. Wertz, J. P. Mercier and O. Bédué, “Cellulose Science and Technology”, CRC Press, (2010), https://www.crcpress.com/Cellulose-Science-and-

Technology/Wertz-Mercier-

Bedue/p/book/9780429131202

8 I. A. Sacui, R. C. Nieuwendaal, D. J. Burnett, S. J. Stranick, M. Jorfi et al., ACS Appl. Mater. Interfaces., 6, 6127 (2014), https://doi.org/10.1021/am500359f

9 W. Chen, H. Yu, Y. Liu, Y. Hai, M. Zhang et al., Cellulose, 18, 433 (2011), https://doi.org/10.1007/s10570-011-9497-z

10 D. Klemm, B. Heublein, H. P. Fink and A. Bohn, Angew. Chem. Int. Ed., 44, 3358 (2005), https://doi.org/10.1002/anie.200460587

11 J. I. Moran, V. A. Alvarez, V. P. Cyras and A. Vázquez, Cellulose, 15, $149 \quad$ (2008), https://doi.org/10.1007/s10570-007-9145-9
12 F. Fahma, S. Iwamoto, N. Hori, T. Iwata and A. Takemura, Cellulose, 18, 443 (2011), https://doi.org/10.1007/s10570-010-9480-0

13 D. Trache, M. H. Hussin, M. M. Haafiz and V. K. Thakur, Nanoscale, 9, $1763 \quad$ (2017), https://doi.org/10.1039/C6NR09494E

14 M. Gama, P. Gatenholm and D. Klemm (Eds.), "Bacterial Nanocellulose: A Sophisticated Multifunctional Material”, CRC Press, 2012, https://www.crcpress.com/Bacterial-NanoCellulose-ASophisticated-Multifunctional-Material/GamaGatenholm-Klemm/p/book/9781138073166

15 M. Iguchi, S. Yamanaka and A. Budhiono, J. Mater. Sci., 35, $261 \quad$ (2000), https://doi.org/10.1023/A:1004775229149

16 H. El-Saied, A. H. Basta and R. H. Gobran, Polym. Plast. Technol. Eng., 43, 797 (2004), https://doi.org/10.1081/PPT-120038065

17 R. M. Brown, Abstr. Pap. Am. Chem. Soc., 227, U303 (2004)

18 B. M. Cherian, A. L. Leao, S. F. de Souza, S. Thomas, L. A. Pothan et al., in "Cellulose Fibers: Bioand Nano-Polymer Composites”, Springer, Berlin, Heidelberg, 2011, p. 539, https://doi.org/10.1007/9783-642-17370-7_21

19 A. Retegi Miner, R. Zuluaga Gallego, P. Gañán Rojo and I. Mondragon, in "Cellulose Based Composites”, Wiley-VCH Verlag GmbH, 2014, p. 63, https://doi.org/10.1002/9783527649440.ch4

20 T. Heinze, in "Cellulose Chemistry and Properties: Fibers, Nanocelluloses and Advanced Materials", Springer International Publishing, 2016, pp. 1-52

21 M. M. Ruiz, J. Y. Cavaille, A. Dufresne, C. Graillat and J. F. Gérard, Macromol. Symp., 169, 211 (2001)

22 P. Sun, C. Sun and S. M. Weinreb, Org. Lett., 3, 3507 (2001), https://doi.org/10.1021/ol010179y

23 K. Fleming, D. G. Gray and S. Matthews, Chem. Eur. J., 7, 1831 (2001), https://doi.org/10.1002/15213765(20010504)7:9<1831::AIDCHEM1831>3.0.CO;2-S

24 S. M. Keshk and K. Sameshima, Enzyme Microb. Technol., $\quad 40, \quad 4$ (2006), https://doi.org/10.1016/j.enzmictec.2006.07.037

25 J. Gong, J. Li, J. Xu, Z. Xiang and L. Mo, RSC Adv., $\quad$ 7, $33486 \quad$ (2017), https://doi.org/10.1039/C7RA06222B

26 J. Buffiere, N. Abad, P. Ahvenainen, J. Dou, M. J. Cocero et al., ACS Sus. Chem. Eng., 2, 16959 (2018), https://doi.org/10.1021/acssuschemeng.8b04296

27 A. D. French, Cellulose, 1, 885 (2014), https://doi.org/10.1007/s10570-013-0030-4

28 K. Kafle, K. Greeson, C. Lee and S. H. Kim, Text. Res. J., 84, $1692 \quad$ (2014), https://doi.org/10.1177/0040517514527379

29 S. H. Kim, C. M. Lee and K. Kafle, Korean J. Chem. Eng., 1, 2127 (2013), https://doi.org/10.1007/s11814-013-0162-0 
30 C. M. Lee, A. Mittal, A. L. Barnette, K. Kafle and Y. B. Park, Cellulose, 20, 991 (2013), https://doi.org/10.1007/s10570-013-9917-3

31 K. Kobayashi, S. Kimura, E. Togawa and M. Wada, Carbohyd. Polym., 83, $483 \quad$ (2011), https://doi.org/10.1016/j.carbpol.2010.08.006

32 J. Li, X. Wei, Q. Wang, J. Chen, G. Chang et al., Carbohyd. Polym., 90, 1609 (2012), https://doi.org/10.1016/j.carbpol.2012.07.038

33 I. Siro, D. Plackett, M. Hedenqvist, M. Ankerfors and T. Lindström, J. Appl. Polym. Sci., 119, 2652 (2011), https://doi.org/10.1002/app.32831

34 Y. Davoudpour, S. Hossain, H. A. Khalil, M. M. Haafiz, Z. M. Ishak et al., Ind. Crop. Prod., 74, 381 (2015), https://doi.org/10.1016/j.indcrop.2015.05.029

35 M. Pääkkö, M. Ankerfors, H. Kosonen, A. Nykänen, S. Ahol et al., Biomacromolecules, 8, 1934 (2007), https://doi.org/10.1021/bm061215p

36 A. Kaushik and M. Singh, Carbohyd. Res., 346, 76 (2011), https://doi.org/10.1016/j.carres.2010.10.020

37 M. L. Hassan, A. P. Mathew, E. A. Hassan, N. A. El-Wakil and K. Oksman, Wood Sci. Technol., 46, 193 (2012), https://doi.org/10.1007/s00226-010-0373-z 38 G. Han, S. Huan, J. Han, Z. Zhang and Q. Wu, $\begin{array}{llll}\text { Materials, } & 7, & 16 & \text { (2013), }\end{array}$ https://doi.org/10.3390/ma7010016

39 N. R. Savadeka, V. S. Karande, N. Vigneshwaran, P. G. Kadam and S. T. Mhaske, Appl. Nanosci., 5, 281 (2015), https://doi.org/10.1007/s13204-014-0316-3

40 A. Ferrer, I. Filpponen, A. Rodríguez, J. Laine and O. J. Rojas, Bioresour. Technol., 125, 249 (2012), https://doi.org/10.1016/j.biortech.2012.08.108

41 W. Wan, M. D. Mozuch, R. C. Sabo, P. Kersten, J. Y. Zhu et al., Cellulose, 22, 351 (2015), https://doi.org/10.1007/s10570-014-0465-2

42 G. Siqueira, S. Tapin-Lingua, J. Bras, D. da Silva Perez and A. Dufresne, Cellulose, 17, 1147 (2010), https://doi.org/10.1007/s10570-010-9449-z

43 T. Taniguchi and K. Okamura, Polym. Int., 47, 291 (1998), https://doi.org/10.1002/(SICI)10970126(199811)47:3<291::AID-PI11>3.0.CO;2-1

44 M. Nuruddin, M. Hosur, M. Uddin, D. Baah and S. Jeelani, J. Appl. Polym. Sci., 133, 42990 (2016), https://doi.org/10.1002/app.42990

45 L. Zhang, T. Tsuzuki and X. Wang, Cellulose, 2, 1729 (2015), https://doi.org/10.1007/s10570-0150582-6

46 V. Baheti and J. Militky, Fiber. Polym., 14, 133 (2013), https://doi.org/10.1007/s12221-013-0133-4

47 S. Iwamoto, A. N. Nakagaito and H. Yano, Appl. Phys. A: Mater. Sci. Proc., 89, 461 (2007), https://doi.org/10.1007/s00339-007-4175-6

48 S. Janardhnan and M. Sain, Bioresources, 1, 176 (2006),

https://ojs.cnr.ncsu.edu/index.php/BioRes/article/view/ BioRes_01_2_176_188_Janardnan_Sain_Isoluation_C ellulose_Microfibrils_Enzymatic
49 B. Wang and M. Sain, Compos. Sci. Technol., 67, 2521 (2007), https://doi.org/10.1016/j.compscitech.2006.12.015

50 A. Alemdar and M. Sain, Bioresour. Technol., 99, 1664

https://doi.org/10.1016/j.biortech.2007.04.029

(2008),

51 A. Chakraborty, M. Sain and M. Kortschot, Holzforschung, 59, 102 (2005), https://doi.org/10.1515/HF.2005.016

52 H. P. Zhao, X. Q. Feng and H. Gao, Appl. Phys. Lett., 90, $073112 \quad$ (2007), https://doi.org/10.1063/1.2450666

53 Q. Cheng, S. Wang and T. G. Rials, Compos. Part A: Appl. Sci. Manuf., 40, 218 (2009), https://doi.org/10.1016/j.compositesa.2008.11.009

54 S. Wang and Q. Cheng, J. Appl. Polym. Sci., 113, 1270 (2009), https://doi.org/10.1002/app.30072

55 P. Chen, H. Yu, Y. Liu, W. Chen, X. Wang et al., Cellulose, 20, 149 (2013), https://doi.org/10.1007/s10570-012-9829-7

56 W. Li, R. Wang and S. Liu BioResources, 6, 4271 (2011),

https://bioresources.cnr.ncsu.edu/BioRes_06/BioRes_0 6_4_4271_Li_Wang_Liu_Nanocryst_Cell_SW_Kraft_ Ultrasonic_Hydrol_1896.pdf

57 S. P. Mishra, A. S. Manent, B. Chabot and C. Daneault, BioResources, 7, 422 (2012), https://ojs.cnr.ncsu.edu/index.php/BioRes/article/view/ BioRes_07_1_0422_Mishra_MCD_Prodn_Nanocellul ose_Various_Options_Ultrasound

58 W. Kamphunthong, P. Hornsby and K. Sirisinha, J. Appl. Polym. Sci., 125, $1642 \quad$ (2012), https://doi.org/10.1002/app.35642

59 T. Kondo, R. Kose, H. Naito and W. Kasai, Carbohyd. Polym., 112, $284 \quad$ (2014), https://doi.org/10.1016/j.carbpol.2014.05.064

60 R. Kose, I. Mitani, W. Kasai and T. Kondo, Biomacromolecules, 12, $716 \quad$ (2011), https://doi.org/10.1021/bm1013469

61 A. Frenot, M. W. Henriksson and P. Walkenström, J. Appl. Polym. Sci., 103, 1473 (2007), doi:10.1002/app.24912

62 H. Xu, Z. Li, D. Zhang, P. Hu and Z. Liu, J. Synth. Fiber. China, 9, $004 \quad$ (2006), https://doi.org/10.1002/app.24912

63 K. Ohkawa, S. Hayashi, A. Nishida, H. Yamamoto and J. Ducreux, Text. Res. J., 79, 1396 (2009), https://doi.org/10.1177/0040517508101455

64 M. G. Freire, A. R. Teles, R. A. Ferreira, L. D. Carlos, J. A. Lopes-da-Silva et al., Green Chem., 13, 3173 (2011), https://doi.org/10.1039/C1GC15930E

65 G. Viswanathan, S. Murugesan, V. Pushparaj, O. Nalamasu, P. M. Ajayan et al., Biomacromolecules, 7, 415 (2006), https://doi.org/10.1021/bm050837s

66 S. L. Quan, S. G. Kang and I. J. Chin, Cellulose, 17, 223 (2010), https://doi.org/10.1007/s10570-0099386- $\mathrm{x}$ 
67 C. L. McCormick, P. A. Callais and B. H. Hutchinson, Macromolecules, 18, 2394 (1987), https://doi.org/10.1021/ma00154a010

68 A. Isogai, N. Mutoh, F. Onabe and M. Usuda, Sen'iGakkaishi, 45, 299 (1989), https://doi.org/10.2115/fiber.45.7_299

69 T. Rosenau, A. Potthast, I. Adorjan, A. Hofinger, H. Sixta et al., Cellulose, 9, 283 (2002), https://doi.org/10.1023/A:1021127423041

70 J. Zhou, L. Zhang and J. Cai, J. Polym. Sci. Part B: Polym. Phys., 42, $347 \quad$ (2004), https://doi.org/10.1002/polb.10636

71 H. Zhang, J. Wu, J. Zhang and J. He, Macromolecules, 38, $8272 \quad$ (2005), https://doi.org/10.1021/ma0505676

72 S. Xu, J. Zhang, A. He, J. Li, H. Zhang et al., Polymer, 49, $2911 \quad$ (2008), https://doi.org/10.1016/j.polymer.2008.04.046

73 Z. Man, N. Muhammad, A. Sarwono, M. A. Bustam, M. V. Kumar et al., J. Polym. Environ., 19, 726 (2011), https://doi.org/10.1007/s10924-011-03233

74 S. K. Mahadeva, J. Kim and C. Jo, Int. J. Precis. Eng. Manuf., 12, 47 (2011), https://doi.org/10.1007/s12541-011-0006-y

75 F. Hermanutz, F. Gähr, E. Uerdingen, F. Meister and B. Kosan, Macromol. Symp., 262, 23 (2008), https://doi.org/10.1002/masy.200850203

${ }^{76}$ C. W. Kim, D. S. Kim, S. Y. Kang, M. Marquez and Y. L. Joo, Polymer, 47, 5097 (2006), https://doi.org/10.1016/j.polymer.2006.05.033

77 B. M. Cherian, A. L. Leão, S. F. de Souza, S. Thomas, L. A. Pothan et al., Carbohyd. Polym., 81, 720

https://doi.org/10.1016/j.carbpol.2010.03.046

(2010)

78 B. Deepa, E. Abraham, B. M. Cherian, A. Bismarck, J. J. Blaker et al., Bioresour. Technol., 102, 1988

https://doi.org/10.1016/j.biortech.2010.09.030

(2011),

79 E. Abraham, B. Deepa, L. A. Pothan, M. Jacob, S. Thomas et al., Carbohyd. Polym., 86, 1468 (2011), https://doi.org/10.1016/j.carbpol.2011.06.034

${ }^{80}$ A. Ashori, M. Babaee, M. Jonoobi and Y. Hamzeh, Carbohyd. Polym., 102, $369 \quad$ (2014), https://doi.org/10.1016/j.carbpol.2013.11.067

81 R. Zuluaga, J. L. Putaux, J. Cruz, J. Vélez, I. Mondragon et al., Carbohyd. Polym., 76, 51 (2009), https://doi.org/10.1016/j.carbpol.2008.09.024

${ }_{82}$ M. F. Rosa, E. S. Medeiros, J. A. Malmonge, K. S. Gregorski, D. F. Wood et al., Carbohyd. Polym., 81, 83

https://doi.org/10.1016/j.carbpol.2010.01.059

(2010),

83 A. C. Corrêa, E. Morais Teixeira, L. A. Pessan and L. H. Mattoso, Cellulose, 17, 1183 (2010), https://doi.org/10.1007/s10570-010-9453-3

${ }^{84}$ H. Kargarzadeh, I. Ahmad, I. Abdullah, A. Dufresne, S. Y. Zainudin et al., Cellulose, 19, 855 (2012), https://doi.org/10.1007/s10570-012-9684-6
85 N. Johar, I. Ahmad and A. Dufresne, Ind. Crop. Prod., $\quad 37, \quad 93 \quad$ (2012), https://doi.org/10.1016/j.indcrop.2011.12.016

86 L. Ludueña, D. Fasce, V. A. Alvarez and P. M. Stefani, BioResources, 6, 1440 (2011), https://ojs.cnr.ncsu.edu/index.php/BioRes/article/view/ BioRes_06_2_1440_Luduena_FAS_Nanocellulose_Ri ce_Husk

${ }^{87}$ J. P. Morais, M. Freitas Rosa, L. D. Nascimento, D. M. Nascimento and A. R. Cassales, Carbohyd. Polym., 91, $229 \quad$ (2013), https://doi.org/10.1016/j.carbpol.2012.08.010

88 P. P. Zhang, D. S. Tong, C. X. Lin, H. M. Yang, Z. K. Zhong et al., Asia-Pacific J. Chem. Eng., 9, 686 (2014), https://doi.org/10.1002/apj.1812

89 V. Kokol, M. Božič, R Vogrinčič and A. P. Mathew, Carbohyd. Polym., 125, 301 (2015), https://doi.org/10.1016/j.carbpol.2015.02.056

90 S. Camarero Espinosa, T. Kuhnt, E. J. Foster and C. Weder, Biomacromolecules, 14, 1223 (2013), https://doi.org/10.1021/bm400219u

91 S. Li, C. Li, M. Yan, Y. Wu, J. Cao et al., Polym. Degrad. Stabil., 98, $1940 \quad$ (2013), https://doi.org/10.1016/j.polymdegradstab.2013.06.017 92 H. Sadeghifar, I. Filpponen, S. P. Clarke, D. F. Brougham and D. S. Argyropoulos, J. Mater. Sci., 46, 7344 (2011), https://doi.org/10.1007/s10853-0115696-0

93 H. Yu, Z. Qin, B. Liang, N. Liu, Z. Zhou et al., J. Mater. Chem., A1, $3938 \quad$ (2013), https://doi.org/10.1039/C3TA01150J

94 P. B. Filson, B. E. Dawson-Andoh and D. Schwegler-Berry, Green Chem., 11, 1808 (2009), https://doi.org/10.1039/B915746H

95 R. Zuluaga, J. L. Putaux, A. Restrepo, I. Mondragon and P. Gañán, Cellulose, 14, 585 (2009), https://doi.org/10.1007/s10570-007-9118-z

96 F. Jiang and Y. L. Hsieh, Carbohyd. Polym., 95, 32 (2013), https://doi.org/10.1016/j.carbpol.2013.02.022

97 F. Tao, H. Song and L. Chou, Carbohyd. Res., 346, 58 (2011), https://doi.org/10.1016/j.carres.2010.10.022 98 T. Saito, Y. Nishiyama, J. L. Putaux, M. Vignon and A. Isogai, Biomacromolecules, 7, 1687 (2006), https://doi.org/10.1021/bm060154s

99 M. Hirota, N. Tamura, T. Saito and A. Isogai, Cellulose, 17, $279 \quad$ (2010), https://doi.org/10.1007/s10570-009-9381-2

${ }^{100} \mathrm{~S}$. Iwamoto, A. Isogai and T. Iwata, Biomacromolecules, 12, $831 \quad$ (2011), https://doi.org/10.1021/bm101510r

${ }^{101}$ K. Xhanari, K. Syverud, G. Chinga-Carrasco, K. Paso and P. Stenius, Cellulose, 18, 257 (2011), https://doi.org/10.1007/s10570-010-9482-y

102 S. Ummartyotin and H. Manuspiya, Renew. Sustain. Energ. Rev., 41, 402 (2015), https://doi.org/10.1016/j.rser.2014.08.050

103 M. Henriksson, G. Henriksson, L. A. Berglund and T. Lindström, Eur. Polym. J., 43, 3434 (2007), https://doi.org/10.1016/j.eurpolymj.2007.05.038 
${ }^{104}$ P. B. Filson and B. E. Dawson-Andoh, Bioresour. Technol., 100, $2259 \quad$ (2009), https://doi.org/10.1016/j.biortech.2008.09.062

${ }^{105}$ D. Mikkelsen, B. M. Flanagan, G. A. Dykes and M. J. Gidley, J. Appl. Microbiol., 107, 576 (2009), https://doi.org/10.1111/j.1365-2672.2009.04226.x

${ }^{106}$ T. Ishida, Y. Sugano, T. Nakai and M. Shoda, Biosci. Biotechnol. Biochem., 66, 1677 (2002), https://doi.org/10.1271/bbb.66.1677

${ }^{107}$ C. Castro, R. Zuluaga, J. L. Putaux, G. Caro, I. Mondragon et al., Carbohyd. Polym., 84, 96 (2011), https://doi.org/10.1016/j.carbpol.2010.10.072

${ }^{108}$ H. J. Song, H. Li, J. H. Seo, M. J. Kim and S. J. Kim, Korean J. Chem. Eng., 26, 141 (2009), https://doi.org/10.1007/s11814-009-0022-0

${ }^{109}$ D. Kralisch, N. Hessler, M. Munteanu, B. Sultanova, D. Klemm et al., Abstr. Pap. Am. Chem. Soc., 241, 1155 (2011)

${ }^{110}$ A. Krystynowicz, W. Czaja, A. WiktorowskaJezierska, M. Gonçalves-Miśkiewicz, M. Turkiewicz et al., J. Ind. Microbiol. Biotechnol., 29, 189 (2002), https://doi.org/10.1038/sj.jim.7000303

${ }^{111}$ S. Kongruang, Appl. Biochem. Biotechnol., 148, 245 (2008), https://doi.org/10.1007/978-1-60327-5262770

${ }^{112}$ K. Watanabe, M. Tabuchi, Y. Morinaga and F. Yoshinaga, Cellulose, 5, $187 \quad$ (1998), https://doi.org/10.1023/A:1009272904582

${ }^{113}$ P. G. Verschuren, T. D. Cardona, M. R. Nout, K. D. De Gooijer and J. C. Van den Heuvel, J. Biosci. Bioeng., $\quad 89, \quad 414 \quad$ (2000), https://doi.org/10.1016/S1389-1723(00)89089-1

${ }^{114}$ H. Kornmann, P. Duboc, I. Marison and U. Von Stockar, Appl. Environ. Microbial., 69, 6091 (2003), https://doi.org/10.1128/AEM.69.10.6091-6098.2003

${ }^{115}$ E. P. Çoban and H. Biyik, Afr. J. Microbiol. Res., 5, 1037 (2011), https://doi.org/10.5897/AJMR11.008

${ }^{116}$ W. Chen, H. Yu, S. Y. Lee, T. Wei, J. Li et al., Chem. Soc. Rev., 47, 2837 (2018), https://doi.org/10.1039/C7CS00790F

${ }^{117}$ B. K. Deka, A. Hazarika, J. Kim, Y. B. Park and H. W. Park, Int. J. Energ. Res., 41, 1397 (2017), https://doi.org/10.1002/er.3707

118 A. Dufresne, "Nanocellulose: From Nature to High Performance Tailored Materials”, Walter de Gruyter GmbH, 2017, https://doi.org/10.1515/9783110254600

${ }^{119} \mathrm{~L}$. Hu and Y. Cui, Energ. Environ. Sci., 5, 6423 (2012), https://doi.org/10.1039/C2EE02414D

${ }^{120}$ L. Hu, N. Liu, M. Eskilsson, G. Zheng, J. McDonough et al., Nano Energ., 2, 1385 (2013), https://doi.org/10.1016/j.nanoen.2012.08.008

${ }^{121}$ H. Lee and S. Choi, Nano Energ., 15, 549 (2015), https://doi.org/10.1016/j.nanoen.2015.05.019

${ }^{122}$ H. Koga, T. Saito, T. Kitaoka, M. Nogi, K. Suganuma et al., Biomacromolecules, 14, 1160 (2013), https://doi.org/10.1021/bm400075f

${ }^{123}$ X. Wu, F. Zhao, J. R. Varcoe, A. E. Thumser, C. Avignone-Rossa et al., Bioelectrochemistry, 77, 64
(2009),

https://doi.org/10.1016/j.bioelechem.2009.05.008

${ }^{124}$ G. Zheng, Y. Cui, E. Karabulut, L. Wågberg, H.

Zhu et al., MRS Bull., 38, 320 (2013), https://doi.org/10.1557/mrs.2013.59

${ }^{125}$ Z. Weng, Y. Su, D. W. Wang, F. Li, J. Du et al., Adv. Energ. Mater., 1, $917 \quad$ (2011), https://doi.org/10.1002/aenm.201100312

${ }^{126}$ X. Chen, H. Lin, P. Chen, G. Guan, J. Deng et al., Adv. Mater., 26, $4444 \quad$ (2014), https://doi.org/10.1002/adma.201400842

${ }^{127}$ B. Dyatkin, V. Presser, M. Heon, M. R. Lukatskaya, M. Beidaghi et al., Chem. Sus. Chem., 6, 2269 (2013), https://doi.org/10.1002/cssc.201300852

128 T. Chen and L. Dai, J. Mater. Chem., A2, 10756 (2014), https://doi.org/10.1039/C4TA00567H

${ }^{129}$ Z. Gui, H. Zhu, E. Gillette, X. Han, G. W. Rubloff et al., ACS Nano, 7, 6037 (2013), https://doi.org/10.1021/nn401818t

${ }^{130}$ L. Bao and X. Li, Adv. Mater., 24, 3246 (2012), https://doi.org/10.1002/adma.201200246

${ }^{131}$ K. Jost, G. Dion and Y. Gogotsi, J. Mater. Chem., A2, $\quad 10776$

(2014), https://doi.org/10.1039/C4TA00203B

${ }^{132}$ U. Gulzar, F. De Angelis, R. P. Zaccaria and C. Capiglia, World J. Text. Eng. Technol., 2, 6 (2016), https://pdfs.semanticscholar.org/ae87/6e0fd4da01817a ac1e51e3ce35a9ff4de1cb.pdf

133 S. Zhai, H. E. Karahan, L. Wei, Q. Qian, A. T. Harris et al., Energ. Storage Mater., 3, 123 (2016), https://doi.org/10.1016/j.ensm.2016.02.003

${ }^{134}$ L. Hu, H. Wu and Y. Cui, Appl. Phys. Lett., 96, 183502 (2010), https://doi.org/10.1063/1.3425767

135 S. Hu, R. Rajamani and X. Yu, Appl. Phys. Lett., 100, 104103 (2012), https://doi.org/10.1063/1.3691948 ${ }^{136}$ A. Razaq, L. Nyholm, M. Sjödin, M. Strømme and A. Mihranyan, Adv. Energ. Mater., 2, 445 (2012), https://doi.org/10.1002/aenm.201100713

137 A. Chiappone, J. R. Nair, C. Gerbaldi, L. Jabbour, R. Bongiovanni et al., J. Power Sources, 196, 10280 (2011), https://doi.org/10.1016/j.jpowsour.2011.07.015 138 A. Chiappone, F. Bella, J. R. Nair, G. Meligrana, R. Bongiovanni et al., Chem. Electro Chem., 1, 1350 (2014), https://doi.org/10.1002/celc.201402051

139 A. Fraiwan, S. Mukherjee, S. Sundermier, H. S. Lee and S. Choi, Biosens. Bioelectron., 49, 410 (2013), https://doi.org/10.1016/j.bios.2013.06.001

${ }^{140}$ A. Fraiwan, H. Lee and S. Choi, IEEE Sens. J., 14, 3385

https://doi.org/10.1109/JSEN.2014.2332075

(2013),

${ }^{141}$ K. H. Kim, K. Y. Lee, J. S. Seo, B. Kumar and S. W. Kim, Small, 7, $2577 \quad$ (2011), https://doi.org/10.1002/smll.201100819

${ }^{142}$ Q. Zhong, J. Zhong, B. Hu, Q. Hu, J. Zhou et al., Energ. Environ. Sci., 6, 1779 (2013), https://doi.org/10.1039/C3EE40592C

${ }^{143}$ X. Gao, L. Huang, B. Wang, D. Xu, J. Zhong et al., ACS Appl. Mater. Interfaces, 8, 35587 (2016), https://doi.org/10.1021/acsami.6b12913 
${ }^{144}$ A. Khan, Z. Abas, H. S. Kim and J. Kim, Sensors, 16, 1172 (2016), https://doi.org/10.3390/s16081172

${ }^{145}$ R. Ding, V. Krikstolaityte and G. Lisak, Sensors Actuators B: Chem., 290, $347 \quad$ (2019), https://doi.org/10.1016/j.snb.2019.03.079

${ }^{146}$ D. S. Tan, M. G. Impas, D. H. Camacho and S. T. Palisoc, Cellulose Chem. Technol., 52, 853 (2018), http://www.cellulosechemtechnol.ro/pdf/CCT910(2018)/p.853-861.pdf

147 S. Parween and A. Asthana, Sensors Actuators B: Chem., 15, 405 (2019), https://doi.org/10.1016/j.snb.2019.01.064

${ }^{148}$ T. Zhou, J. J. Liu, Y. Xu and Z. Y. Wu, Microchem. J., 1, $703 \quad$ (2019), https://doi.org/10.1016/j.microc.2018.10.022

${ }^{149}$ C. Puangbanlang, K. Sirivibulkovit, D. Nacapricha and Y. Sameenoi, Talanta, 1, 542 (2019), https://doi.org/10.1016/j.talanta.2019.02.048

${ }^{150}$ F. Ciolacu, Cellulose Chem. Technol., 52, 863 (2018),

http://www.cellulosechemtechnol.ro/pdf/CCT910(2018)/p.863-871.pdf

${ }^{151}$ L. M. Fu and Y. N. Wang, Trends Anal. Chem., 107, 196

(2018),

https://doi.org/10.1016/j.trac.2018.08.018

${ }^{152}$ X. Wang, Y. Guo, D. Li, H. Chen and R. C. Sun, Chem. Commun., 48, 5569 (2012), https://doi.org/10.1039/C2CC30208J

${ }^{153}$ L. Lin, Y. Hu, C. Xu, Y. Zhang, R. Zhang et al., Nano Energy, 2, 75 (2013), https://doi.org/10.1016/j.nanoen.2012.07.019

${ }^{154}$ C. Yan, J. Wang, W. Kang, M. Cui, X. Wang et al., Adv. Mater., 26, $2022 \quad$ (2014), https://doi.org/10.1002/adma.201304742

${ }^{155}$ X. Wu, C. Lu, Y. Han, Z. Zhou, G. Yuan et al., Compos. Sci. Technol., 124, 44 (2016), https://doi.org/10.1016/j.compscitech.2016.01.012

${ }^{156}$ M. Prabaharan and J. F. Mano, Macromol. Biosci., 6, 991 (2006), https://doi.org/10.1002/mabi.200600164 157 Z. Zhang, L. Chen, C. Zhao, Y. Bai, M. Deng et al., Polymer, $\quad 52, \quad 676 \quad$ (2011), https://doi.org/10.1016/j.polymer.2010.12.048

${ }^{158}$ J. Xie and J. Li, J. Bioresour. Bioprod., 2, 1 (2017), http://www.bioresources-

bioproducts.com/index.php/bb/article/view/125

159 J. V. Edwards, N. Prevost, A. French, M. Concha, A. DeLucca et al., Engineering, 5, 20 (2013), https://doi.org/10.4236/eng.2013.59A003

160 J. R. Navarro, S. Wennmalm, J. Godfrey, M. Breitholtz and U. Edlund, Biomacromolecules, 17, 1101 https://doi.org/10.1021/acs.biomac.5b01716

${ }^{161}$ A. Kafy, A. Akther, M. I. Shishir, H. C. Kim, Y. Yun et al., Sensors Actuators A: Phys., 247, 221 (2016), https://doi.org/10.1016/j.sna.2016.05.045

${ }^{162}$ R. K. Mangayil, S. M. Rajala, A. J. Pammo, E. L. Sarlin, J. Luo et al., ACS Appl. Mater. Interfaces, 9, 19048 (2017), https://doi.org/10.1021/acsami.7b04927
${ }^{163}$ R. Weishaupt, G. Siqueira, M. Schubert, M. M. Kämpf, T. Zimmermann et al., Adv. Funct. Mater., 27, 1604291 https://doi.org/10.1002/adfm.201604291

${ }^{164}$ K. K. Sadasivuni, A. Kafy, L. Zhai, H. U. Ko, S. Mun et al., Small, 11, 994 (2015), https://doi.org/10.1002/smll.201402109

${ }^{165}$ Y. Okahisa, A. Yoshida, S. Miyaguchi and H. Yano, Compos. Sci. Technol., 69, 1958 (2009), https://doi.org/10.1016/j.compscitech.2009.04.017

${ }^{166}$ H. Yano, J. Sugiyama, A. N. Nakagaito, M. Nogi, T. Matsuura et al., Adv. Mater., 17, 153 (2005), https://doi.org/10.1002/adma.200400597

167 S. Iwamoto, A. N. Nakagaito, H. Yano and M. Nogi, Appl. Phys. A: Mater. Sci. Proc., 81, 1109 (2005), https://doi.org/10.1007/s00339-005-3316-z

${ }^{168}$ H. Ono, Y. Shimaya, K. Sato and T. Hongo, Polym. J., 36, 684 (2004), https://doi.org/10.1295/polymj.36.684

169 S. Ifuku, M. Nogi, K. Abe, K. Handa, F. Nakatsubo et al., Biomacromolecules, 8, 1973 (2007), https://doi.org/10.1021/bm070113b

170 A. Mihranyan, A. P. Llagostera, R. Karmhag, M. Strømme and R. Ek, Int. J. Pharm., 269, 433 (2004), https://doi.org/10.1016/j.ijpharm.2003.09.030

${ }^{171}$ D. Le Bras, M. Strømme and A. Mihranyan, J. Phys. Chem. B, 119, 5911 (2015), https://doi.org/10.1021/acs.jpcb.5b00715

172 J. Huang, Y. Zhou, L. Dong, Z. Zhou and R. Liu, Compos. Sci. Technol., 138, 40 (2017), https://doi.org/10.1016/j.compscitech.2016.11.020

${ }^{173}$ K. Littunen, U. Hippi, L. S. Johansson, M. Österberg, T. Tammelin et al., Carbohyd. Polym., 84, 1039

(2011), https://doi.org/10.1016/j.carbpol.2010.12.064

${ }^{174}$ P. Stenstad, M. Andresen, B. S. Tanem and P. Stenius, Cellulose, 15, $35 \quad$ (2008), https://doi.org/10.1007/s10570-007-9143-y

${ }^{175}$ G. Siqueira, J. Bras, N. Follain, S. Belbekhouche, S. Marais et al., Carbohyd. Polym., 91, 711 (2013), https://doi.org/10.1016/j.carbpol.2012.08.057

${ }^{176}$ H. Yuan, Y. Nishiyama, M. Wada and S. Kuga, Biomacromolecules, 7, $696 \quad$ (2006), https://doi.org/10.1021/bm050828j

${ }^{177}$ J. T. Korhonen, M. Kettunen, R. H. Ras and O. Ikkala, ACS Appl. Mater. Interfaces, 3, 1813 (2011), https://doi.org/10.1021/am200475b 